EIMOD ADSGE MODEL FOR FISCAL 2011 policy SIMU Lations

Nikolar stähler and Carlos thomas

Documentos de Trabajo. N. 1110

\title{
BANCOUE ESPANA
}

\author{
Eurosistema
}


FIMOD - A DSGE MODEL FOR FISCAL POLICY SIMULATIONS 
FIMOD - A DSGE MODEL FOR FISCAL POLICY SIMULATIONS ${ }^{(*)}$

\author{
Nikolai Stähler ${ }^{(* *)}$ \\ DEUTSCHE BUNDESBANK
}

Carlos Thomas ${ }^{(* *)}$

BANCO DE ESPAÑA

${ }^{*}$ ) The opinions expressed in this paper do not necessarily reflect the views of the Banco de España, the Deutsche Bundesbank, the Eurosystem or its staff. Any errors are ours alone. We would like to thank Francisco de Castro, Michael Krause, Jana Kremer, Stéphane Moyen, Eva María Ortega, Javier José Pérez, Céline Poilly, Christian Schumacher, Karsten Wendorff and an anonymous referee for their helpful comments. The paper also benefited greatly from discussions in the European System of Central Bank's (ESCB) Working Group on Econometric Modelling (WGEM), from the Banque de France workshop "Structural Analysis in Times of Crisis" and the Annual Meeting of the Spanish Public Economics Society. Nikolai Stähler gratefully acknowledges the hospitality of the Banco de España where a significant part of this work has been undertaken.

${ }^{(\star)}$ Deutsche Bundesbank, Economics Department, Public Finance Division, Wilhelm-Epstein-Str. 14, 6043 Frankfurt a.M., Germany, e-mail: nikolai.staehler@bundesbank.de.

$\left.{ }^{(\star \star}\right)$ Banco de España, Research Department, Calle Alcalá 48, 28014 Madrid, Spain, e-mail: carlos.thomas@bde.es. 
The Working Paper Series seeks to disseminate original research in economics and finance. All papers have been anonymously refereed. By publishing these papers, the Banco de España aims to contribute to economic analysis and, in particular, to knowledge of the Spanish economy and its international environment.

The opinions and analyses in the Working Paper Series are the responsibility of the authors and, therefore, do not necessarily coincide with those of the Banco de España or the Eurosystem.

The Banco de España disseminates its main reports and most of its publications via the INTERNET at the following website: http://www.bde.es.

Reproduction for educational and non-commercial purposes is permitted provided that the source is acknowledged.

() BANCO DE ESPAÑA, Madrid, 2011

ISSN: 0213-2710 (print)

ISSN: 1579-8666 (on line)

Depósito legal: M. 21860-2011

Unidad de Publicaciones, Banco de España 


\section{Abstract}

This paper develops a medium-scale dynamic, stochastic, general equilibrium (DSGE) model for fiscal policy simulations. Relative to existing models of this type, our model incorporates two important features. First, we consider a two-country monetary union structure, which makes it well suited to simulate fiscal measures by relatively large countries in a currency area. Second, we provide a notable degree of disaggregation on the government expenditures side, by explicitly distinguishing between (productivity-enhancing) public investment, public purchases and the public sector wage bill. In addition, we consider a labor market characterized by search and matching frictions, which allows to analyze the response of equilibrium unemployment to fiscal measures. In order to illustrate some of its applications, and motivated by recent policy debate in the Euro Area, we calibrate the model to Spain and the rest of the area and simulate a number of fiscal consolidation scenarios. We find that, in terms of output and employment losses, fiscal consolidation is the least damaging when achieved by reducing the public sector wage bill, whereas it is most damaging when carried out by cutting public investment.

Keywords: DSGE model, fiscal policy, two-country monetary union, disaggregation of fiscal expenditures, labor market frictions.

JEL classification: E62, H30. 


\section{Resumen}

Este artículo presenta un modelo de equilibrio general dinámico y estocástico, de tamaño medio, para simulaciones de política fiscal. Respecto de otros modelos de este tipo, nuestro modelo incorpora dos características importantes. Por un lado, consideramos una estructura de unión monetaria con dos países, lo cual la hace bien indicada para simular medidas fiscales por parte de países grandes dentro de una unión monetaria. Segundo, proporcionamos un grado notable de desagregación del gasto público, distinguiendo explícitamente entre inversión pública (que tiene efectos positivos sobre la productividad), compras netas y salarios públicos. Además, consideramos un mercado laboral con fricciones de búsqueda y emparejamiento, lo cual permite analizar la respuesta del desempleo a medidas fiscales. Para ilustrar alguna de sus aplicaciones, y motivados por los debates recientes en el seno de la zona euro, calibramos el modelo para España y el resto de la UEM y simulamos una serie de escenarios de consolidación fiscal. Encontramos que, en términos de producción y empleo, la manera menos dañina de realizar una consolidación fiscal es reducir los salarios del sector público, mientras que la manera más costosa es recortar la inversión pública.

Palabras claves: Modelo DSGE, política fiscal, unión monetaria de dos países, desagregación del gasto público, fricciones del mercado laboral.

Códigos JEL: E62, H30. 


\section{Introduction}

The recent crisis has obliged governments around the world to put in place ambitious fiscal stimulus plans and the ensuing fiscal consolidation (or "exit") strategies in order to assure fiscal stability. The latter issue is moving center stage in current public debates. In order to bring fiscal balances back on track, fiscal authorities mainly have the possibility of increasing taxes and/or cutting public spending. But which taxes should be increased? Which spending components should be cut? All across Europe, countries such as Germany, Greece, Portugal, Spain and others have put forward consolidation plans that include cuts in public employment, public wages and public investment as well as increases in VAT and labor income tax rates. Which consequences can we expect from these measures on, among others, output, unemployment or international competitiveness? What are the short-run costs and long-run benefits of such measures? In this paper, we present "FiMod - A DSGE Model for Fiscal Policy Simulations", a dynamic, stochastic, general equilibrium (DSGE) model jointly developed by Banco de España and Deutsche Bundesbank staff in order to address exactly such kind of questions. The model has been used for policy simulations in the Working Group on Econometric Modelling (WGEM) of the European System of Cenrtal Banks (ESCB).

DSGE models provide a reliable tool for evaluating alternative policy measures. For this reason, fiscal policy analysis in DSGE models has gained momentum recently. The applications of such models include the assessment of temporary versus permanent fiscal stimulus, the assessment of structural changes in public tax and spending policy, the analysis of fiscal multipliers and the role of private demand as well as fiscal policy's interaction with monetary policy (in particular, at the zero-lower bound). Without completeness, relevant studies include Galí and Monacelli (2008), who analyze optimal fiscal and monetary policy in a currency union; Coenen et al. (2008), who simulate structural tax reforms based on the European Central Bank's New Area Wide Model (NAWM; see Christoffel et al. 2008); Boscá et al. (2009a, 2009b, 2010), who analyze several policy measures based on the REMS model, which is used by the Spanish Ministry of Finance; Colciago et al. (2009), who assess the role of automatic stabilizers in a monetary union; Christiano et al. (2009), Cogan et al. (2009) and Hall (2009), all of which analyze fiscal multipliers; and Eggertsson (2009) and Erceg and Lindé (2010), who assess fiscal policy at the zero-lower bound. Freedman et al. (2009) address the question of potential short-run benefits and long-run costs of fiscal deficits, while Coenen et al. (2010a, 2010b) and Hebous (2010) provide a comprehensive overview of the effects of fiscal policy stimulus in structural models. Several institutions and authors, including some of the ones mentioned above, are working on improving their models in order to be better able to picture relevant fiscal policy features. ${ }^{1}$

Our framework contributes to the literature on medium-scale DSGE models for fiscal policy analysis in two important ways. First, the model incorporates a two-country monetary union structure. This makes it well suited to analyze fiscal policy measures by large countries in a monetary union, as is the case of Germany, France, Italy or Spain inside the European Monetary Union (EMU). The two-country structure allows to consider the spillover effects of fiscal actions in one country to the other, and vice versa. Most of the models men-

\footnotetext{
${ }^{1}$ For example, members of the European System of Central Banks (ESCB) are conducting fiscal policy simulations in their DSGE models such as the Bank of Portugal in PESSOA (see, for example, Almeida et al., 2010), the Bank of Finland in Aino (e.g. Kilponen and Ripatti, 2005) and the European Central Bank in the EAGLE-model (see Gomes et al., 2010). Also, the EU Commission is further activating their Quest III-model to conduct fiscal policy analyses (see Ratto et al., 2009).
} 
tioned above focus either on large economies with an independent monetary policy reaction function, or on small open economies that do not influence the rest of the world. Second, we provide a notable degree of disaggregation on the fiscal expenditures side. In particular, we explicitly distinguish between public investment and public consumption; the latter in turn is divided between public purchases and the public sector wage bill. Each of these components has a distinct effect on the rest of the economy. The model thus allows to simulate specific measures that have been implemented recently in a number of European countries, such as cuts in public sector wages and/or employment, and reductions in public investment. Fiscal expenditures are completed with a number of transfers to the private sector, including unemployment benefits and lump-sum subsidies. On the fiscal revenues side, the model considers also a wide range of taxes, including taxes on consumption, labor income, returns on bond holdings and on physical capital, and social security contributions. In addition, our model incorporates the modern theory of equilibrium unemployment by introducing search and matching frictions in the labor market, along the lines of Pissarides (2000); this allows us to study the effects of fiscal actions on unemployment. Finally, following Galí et al. (2007) we assume the existence of rule-of-thumb (RoT) households, which allows us to consider non-Ricardian effects of fiscal policy. ${ }^{2}$

For the purpose of illustration, we calibrate the home country in the model to Spain and the foreign country to the rest of the EMU. We then use the calibrated model to simulate some of the measures recently implemented or announced by the Spanish fiscal authorities. In particular, we simulate reductions in public sector wages and public employment. Since the public wage bill is a component of public consumption, it is interesting to compare the resulting effects to those stemming from a reduction in public purchases, the component that most closely resembles the usual definition of 'government consumption' in DSGE models. We also analyze a decrease in public investment, which differs from public consumption in that the stock of public capital (for example, infrastructures) has a beneficial effect on private sector productivity. Regarding the fiscal revenues side, we simulate increases in VAT and labor income tax rates. In order to make all these measures comparable, we calibrate the change in each fiscal instrument so as to produce an (ex-ante) reduction in the primary deficit to GDP ratio of one percentage point. All measures are assumed to be permanent, which allows us to assess short-run and long-run effects. Furthermore, we assume that the long-run fiscal saving resulting from lower interest payments on outstanding debt is used to reduce labor income taxes, which allows us to capture the long-run benefits of fiscal consolidation.

Our results can be summarized as follows. Fiscal consolidation is most damaging (in terms of output and employment losses) when performed via public investment cuts, both in the short and the long-run. Most of the short-run effects are driven by the direct effect of public investment on aggregate demand, whereas the negative long-run effects are mainly the result of the gradual decline in the public capital stock and thus in private-sector productivity. A cut in public purchases has similar (although slightly smaller) contractionary effects in the short-run, whereas the long-run effects are positive thanks to the reduction in distortionary labor income taxation. By contrast, reductions in public sector employment or wages are the least damaging alternatives. First, the public sector wage bill is not a component of

${ }^{2}$ Our integration of search and matching frictions and RoT households follows Boscá et al. (2010), who are to our knowledge the first to have incorporated both features into a medium-scale DSGE model for fiscal policy simulations. 
aggregate demand for privately-produced goods and services. Second, both measures have positive spillovers on private-sector employment and output, because they lower workers' outside option in wage negotiations, which allows firms to reduce their labor costs and thus improve their international competitiveness. ${ }^{3}$ With regard to taxation, we find that an increase in the labor income tax rate has relatively small contractionary effects on output and employment. In a standard search and matching framework, unlike in neoclassical models of the labor market, labor income taxation does not affect labor supply per se, which is vertical at the level of the labor force; however, it does raise wage claims by matched workers and hence the resulting wage agreements. Our results suggest that the bargaining process in a matching framework partially dampens the effects of labor income taxation on employment. An increase in the consumption tax rate has comparable short-run effects on economic activity, for similar reasons. Finally, we simulate a measure usually referred to as 'fiscal devaluation' - conducted in Germany in 2007 and currently under discussion in several EMU member countries-, where we decrease the consumption tax rate and let a reduction in social security contributions (instead of labor income taxes) absorb the saving in interest payments on public debt; we find that such a measure would favor the Spanish economy thanks to the reduction in labor costs, while the spillovers to the rest of EMU would be rather small but positive.

The rest of this paper is organized as follows. The model is presented in section 2 . Section 3 evaluates the impact of the policy measures announced by the Spanish government. We also focus on the comparison of a reduction in public employment and public wages, respectively, to a decrease in public purchases (the way a cut in public consumption has conventionally been modelled so far). Furthermore, we differentiate between short and long-run effects. In Section 4, we present an analysis in which long-run proceeds of increasing VAT are used to cut social security contributions. Section 5 concludes.

\section{The model}

This section presents the details of FiMod, a dynamic stochastic general equilibrium framework which is especially suitable for the analysis of fiscal policy issues. It is currently calibrated for Spain in the European Monetary Union (EMU). However, it can easily be recalibrated to fit the characteristics of any other monetary union economy. The calibration strategy is also detailed at the end of this section.

We consider a two-country monetary union in which we normalize population size to unity, of which $\omega \in(0,1)$ live in the home country (Spain), while the remaining $(1-\omega)$ live in the foreign country (rest of EMU). Throughout the paper, quantity variables will be expressed in per capita terms, unless otherwise indicated; aggregate quantities can easily be obtained by multiplying per capita quantities by each country's population. Both regions are modeled analogously, while we allow structural parameters to differ. Each country is inhabited by households who consume home and foreign consumption goods and supply

\footnotetext{
${ }^{3}$ Both measures differ though in their effects on GDP and total employment. In national accounts, GDP is defined as the sum of private-sector production and government production, where the latter is valued at input costs (i.e. the government wage bill); whereas ceteris paribus a cut in government wages affects only the GDP deflator (thus leaving real GDP unchanged), the reduction in public employment implies a reduction in real government production and hence in real GDP. Regarding total employment, the cut in public wages improves private-sector and therefore total employment, whereas a reduction in public employment dominates the positive spillover to private-sector employment and thus lowers total employment.
} 
labor. Following Galí et al. (2007), we assume that only a fraction of households can buy and sell assets (in particular, physical capital, domestic government debt and international bonds), while the rest consume their disposable income and thus behave in a non-Ricardian fashion. Both types of household also enjoy utility from government services.

Private production is split in three sub-sectors. Retailers buy intermediate goods varieties, bundle these into a final good and sell the latter to the home and foreign market under perfect competition. We assume that there is no price discrimination between the two markets. Intermediate goods producers use labor services and private capital as production inputs. Cost minimization determines the amounts of each input used per firm. As sellers of differentiated products, intermediate goods-producing firms enjoy monopolistic power and are thus able to set their nominal price, which they do in a staggered manner following Calvo (1983). Furthermore, the stock of public capital (infrastructures, etc.) enters the private production function and thus increases private sector productivity. Finally, a sector of labor firms search for unemployed workers in a frictional labor market, hire them, produce labor services and sell these to the intermediate goods sector for a perfectly competitive price. Except for the frictional labor market structure, the production sector is similar to Smets and Wouters $(2003,2007)$ or Christiano et al. (2005) and can thus be considered standard.

The labor market is characterized by search and matching frictions, in the tradition of Pissarides (2000). This implies that it takes time for unemployed workers and vacant jobs to be matched and, therefore, generates involuntary unemployment. We assume that both private firms and the government search in the same pool of unemployment, which means that unemployed individuals may find a job in either of the two sectors. Wages in the private sector are set in a staggered manner along the lines of Bodart et al. (2006), Christoffel et al. (2009) and de Walque et al. (2009). The wage bargaining is undertaken by a union. The public sector wage and employment levels are autonomously set by the government as in Quadrini and Trigari (2007), Afonso and Gomes (2008) or Gomes (2009).

The government is split into monetary and fiscal policy. The monetary authority sets the nominal area-wide reference interest rate (i.e. the ECB rate) according to a Taylor-type rule that responds to measured area-wide inflation and output gap. Fiscal policy is conducted autonomously in each country. National fiscal authorities finance themselves with taxes on consumption, wage income and returns on capital and bond investments, as well as with social security contributions, lump-sum taxes and debt. Furthermore, each fiscal authority can issue public debt. On the other hand, each government spends in privatelyproduced consumption and investment goods, public sector wages, unemployment benefits, lump-sum subsidies, and interest payments on outstanding debt.

We will start by describing the household sector in section 2.1. Then, we turn to the production sector in section 2.2, while section 2.3 details the labor market. Fiscal authorities are described in section 2.4, followed by a description of international linkages in section 2.5 where we also detail the monetary policy rule and derive the missing equilibrium conditions, while the calibration strategy is explained in section 2.6.

\subsection{Households}

Following Galí et al. (2007), we assume that each country is populated by a share $(1-\mu)$ of optimizing (or Ricardian) households who have unrestricted access to capital markets and are therefore able to substitute consumption intertemporally. The remaining share $\mu \in[0,1)$ of households is considered to be liquidity-constrained in the sense that they can neither 
save nor borrow and, thus, consume all their labor income in each period, i.e. they behave in a non-Ricardian fashion. This household type has become known as 'rule-of-thumb' household in the literature. Each household has a continuum of members of size one. The welfare function of each type of representative household is given by

$$
E_{0}\left\{\sum_{t=0}^{\infty} \beta^{t} \cdot u_{t}\left(c_{t}^{i}, c_{t-1}^{i}, \tilde{g}_{t}\right)\right\}
$$

where $E_{t}$ is the expectations operator conditional on time- $t$ information, $c_{t}^{i}$ denotes household consumption of final goods, and the superscripts $i=o, r$ denote optimizing and ruleof-thumb households, respectively. The variable $\tilde{g}_{t}$ is government services produced by public employees, which is taken as given by private households. The instantaneous utility function is given by

$$
u\left(c_{t}^{i}, c_{t-1}^{i}, \tilde{g}_{t}\right)=\left\{\begin{array}{ll}
\frac{\left[c_{t}^{i}-h \cdot c_{t-1}^{i}\right]^{1-\sigma_{c}}-1}{1-\sigma_{c}}+\zeta \cdot \frac{\tilde{g}_{t}^{1-\sigma_{c}}-1}{1-\sigma_{c}}, & \sigma_{c}>0, \sigma_{c} \neq 1 \\
\log \left[c_{t}^{i}-h \cdot c_{t-1}^{i}\right]+\zeta \cdot \log \left[\tilde{g}_{t}\right], & \sigma_{c}=1
\end{array} .\right.
$$

The parameter $\sigma_{c}$ is the coefficient of relative risk aversion (equal to the inverse of the intertemporal elasticity of substitution), $h$ denotes the degree of habit formation in consumption, and $\zeta>0$ is a parameter capturing the relative valuation of public consumption in the households' utility function.

Inside each household, its members may be employed in the public sector, in the private sector, or unemployed. We assume full consumption insurance within the household, as in Andolfatto (1996) or Merz (1995). This holds both for Ricardian and rule-of-thumb households. In this regard, our specification of rule-of-thumb households differs somewhat from Galí et al. (2007); see also Boscá et al. (2009a, 2009b, 2010) for a more detailed explanation. However, the level of unemployment affects the disposable income of rule-of-thumb households, such that they still face a true income risk from employment fluctuations.

We assume that both countries trade consumption and investment goods as well as international nominal bonds. Trade in goods is modelled as follows. The consumption basket of a type- $i$ household in the home country is given by

$$
c_{t}^{i}=\left(\frac{c_{A t}^{i}}{\omega+\psi}\right)^{\omega+\psi}\left(\frac{c_{B t}^{i}}{1-\omega-\psi}\right)^{1-\omega-\psi},
$$

where $c_{A t}^{i}$ and $c_{B t}^{i}$ are consumption of goods produced in country A (home) and B (foreign), respectively, and $\psi$ is a parameter capturing the degree of home bias in consumption. Cost minimization by the household implies,

$$
\frac{c_{A t}^{i}}{c_{B t}^{i}}=\frac{\omega+\psi}{1-\omega-\psi} \frac{P_{B t}}{P_{A t}}
$$

where $P_{A t}$ and $P_{B t}$ are the producer price indexes (PPI) in countries A and B, respectively. From now onwards, let

$$
p_{B t} \equiv \frac{P_{B t}}{P_{A t}}
$$


denote the terms of trade. Analogously, production technologies make use of a combination of investment goods produced in both countries. The basket of investment goods (which are assumed to be owned by type-o households only) is given by

$$
I_{t}^{o}=\left(\frac{I_{A t}^{o}}{\omega+\psi}\right)^{\omega+\psi}\left(\frac{I_{B t}^{o}}{1-\omega-\psi}\right)^{1-\omega-\psi}
$$

where $I_{A t}^{o}$ and $I_{B t}^{o}$ are investment in goods produced in country A and B, respectively. Again, cost minimization implies that

$$
\frac{I_{A t}^{o}}{I_{B t}^{o}}=\frac{\omega+\psi}{1-\omega-\psi} p_{B t}
$$

The above equations imply that nominal expenditure in consumption and investment goods equal $P_{A t} c_{A t}^{i}+P_{B t} c_{B t}^{i}=P_{t} c_{t}^{i}$ and $P_{A t} I_{A t}^{o}+P_{B t} I_{B t}^{o}=P_{t} I_{t}^{o}$, respectively, where

$$
P_{t}=\left(P_{A t}\right)^{\omega+\psi}\left(P_{B t}\right)^{1-\omega-\psi}
$$

is the corresponding before-VAT consumer price index (before-VAT CPI). Notice that $P_{t}=$ $P_{A t} \cdot p_{B t}^{1-\omega-\psi}$. Therefore, before-VAT CPI inflation, $\pi_{t} \equiv P_{t} / P_{t-1}$, evolves according to

$$
\pi_{t}=\pi_{A t}\left(\frac{p_{B t}}{p_{B t-1}}\right)^{1-\omega-\psi}
$$

where $\pi_{A t} \equiv P_{A t} / P_{A t-1}$ is PPI inflation in country A. In practice, consumer price indexes are constructed with after-VAT prices, which in our model correspond to $P_{t}\left(1+\tau_{t}^{c}\right)$. For this reason, we also define after-VAT CPI inflation,

$$
\pi_{t}^{\tau^{c}} \equiv \pi_{t} \cdot \frac{1+\tau_{t}^{c}}{1+\tau_{t-1}^{c}}
$$

which will be the relevant inflation measure to be taken into account by the monetary authority. From now onwards, however, we will simply use 'CPI' in order to refer to 'before-VAT CPI'.

\subsubsection{Optimizing households}

In order to calculate households' optimal choices, we first have to describe the budget constraints they are facing. Each optimizing households' real labor income (gross of taxes) is given by $w_{t}^{p} n_{t}^{p, o}+w_{t}^{g} n_{t}^{g, 0}$, where $w_{t}^{p}$ is the average real wage in the private sector (to be derived later), $w_{t}^{g}$ is the real wage in the government sector, and $n_{t}^{p, o}$ and $n_{t}^{g, o}$ are the number of type-o household members employed in the private and government sector, respectively. Wages are taxed by the government at rate $\tau_{t}^{w}$. When unemployed, the household member receives unemployment benefits $\kappa^{B}$. Consumption expenditures are taxed at rate $\tau_{t}^{c}$. The household can invest in physical capital $k_{t}^{o}$, which earns a real rental rate $r_{t}^{k}$ and depreciates at rate $\delta^{k}$. Returns on physical capital (net of depreciation allowances) are taxed at rate $\tau_{t}^{k}$. The latter can be seen as a proxy for corporate taxes, as private investment decisions are assumed to be made by households. The optimizing household can also purchase nominal government bonds $B_{t}^{o}$, which pay a gross nominal interest rate $R_{t}$. Returns on government 
bonds are taxed at the rate $\tau_{t}^{b}$. Finally, optimizing households can hold international nominal bonds, $D_{t}^{o}$. In order to ensure stationarity of equilibrium, we follow Schmitt-Grohé and Uribe (2003) and assume that home agents pay a risk-premium (on top of the area-wide nominal policy rate, which we denote by $R_{t}^{e c b}$ ) that increases with the country's net foreign asset position. In particular we assume that the nominal interest rate paid or received by home investors is given by $R_{t}^{e c b} \exp \left(-\psi_{d}\left(d_{t}-\bar{d}\right) / Y_{t}\right)$, with $\psi_{d}>0$, where $d_{t} \equiv D_{t} / P_{A t}, D_{t}$ is the home country's nominal net foreign asset position and $(-) d_{t} / Y_{t}$ is the ratio of net foreign debt over output. We assume for simplicity that trade in international bonds is not taxed. Taking these elements together, the budget constraint of the representative optimizing households in real terms reads

$$
\begin{aligned}
\left(1+\tau_{t}^{c}\right) c_{t}^{o}+I_{t}^{o}+\frac{B_{t}^{o}+D_{t}^{o}}{P_{t}}+ & \frac{T_{t}}{1-\mu}=\frac{\Pi_{t}}{P_{t}}+\left(\left(1-\tau_{t}^{k}\right) r_{t}^{k}+\tau_{t}^{k} \delta^{k}\right) k_{t-1}^{o} \\
& +\frac{R_{t-1} B_{t-1}^{o}}{P_{t}}+\frac{R_{t-1}^{e c b} e^{-\psi_{d}\left(d_{t-1}-\bar{d}\right) / Y_{t-1} D_{t-1}^{o}}}{P_{t}} \\
& -\tau_{t}^{b} \frac{\left(R_{t-1}-1\right) B_{t-1}^{o}}{P_{t}}+\frac{S u b_{t}}{1-\mu} \\
& +\left(1-\tau_{t}^{w}\right)\left(w_{t}^{p} n_{t}^{p, o}+w_{t}^{g} n_{t}^{p, g}\right)+\left(1-n_{t}^{p, o}-n_{t}^{g, o}\right) \kappa^{B},
\end{aligned}
$$

where $\Pi_{t}$ are nominal per capita profits from firms (which are assumed to be owned by the optimizing households) redistributed in a lump-sum manner, and $T_{t}$ and $S u b_{t}$ are lump-sum taxes and subsidies, respectively. The law of motion of private physical capital is given by

$$
k_{t}^{o}=\left(1-\delta^{k}\right) k_{t-1}^{o}+\left[1-S\left(I_{t}^{o} / I_{t-1}^{o}\right)\right] I_{t}^{o},
$$

where $S\left(I_{t}^{o} / I_{t-1}^{o}\right)=\frac{\kappa_{I}}{2}\left(I_{t}^{o} / I_{t-1}^{o}-1\right)^{2}$ represents investment adjustment costs (see Christiano et al., 2005; for a discussion). Maximizing (1) given (2) subject to equations (3) and (4) yields the following standard first-order conditions,

$$
\begin{aligned}
& \text { for } c_{t}^{o}: \quad \lambda_{t}^{o}=\frac{\left[c_{t}^{o}-h \cdot c_{t-1}^{o}\right]^{-\sigma_{c}}-\beta \cdot h \cdot E_{t}\left\{\left[c_{t+1}^{o}-h \cdot c_{t}^{o}\right]^{-\sigma_{c}}\right\}}{\left(1+\tau_{t}^{c}\right)}, \\
& \text { for } B_{t}^{o}: \quad \lambda_{t}^{o}=\beta \cdot E_{t}\left\{\lambda_{t+1}^{o} \cdot \frac{R_{t} \cdot\left(1-\tau_{t+1}^{b}\right)+\tau_{t+1}^{b}}{\pi_{t+1}}\right\} \text {, } \\
& \text { for } k_{t}^{o}: \quad Q_{t}=\beta \cdot E_{t}\left\{\frac{\lambda_{t+1}^{o}}{\lambda_{t}^{o}}\left[\left(1-\delta^{k}\right) Q_{t+1}+\left(1-\tau_{t+1}^{k}\right) \cdot r_{t+1}^{k}+\tau_{t+1}^{k} \cdot \delta^{k}\right]\right\} \text {, } \\
& \text { for } I_{t}^{o}: \quad 1=Q_{t}\left[1-S\left(I_{t}^{o} / I_{t-1}^{o}\right)-I_{t}^{o} \cdot S^{\prime}\left(I_{t}^{o} / I_{t-1}^{o}\right)\right] \\
& +\beta \cdot E_{t}\left\{\frac{\lambda_{t+1}^{o}}{\lambda_{t}^{o}} Q_{t+1} \frac{I_{t+1}^{o}{ }^{2}}{I_{t}^{o}} S^{\prime}\left(I_{t+1}^{o} / I_{t}^{o}\right)\right\} \quad, \\
& \text { for } D_{t}^{o}: \quad \lambda_{t}^{o}=\beta R_{t}^{e c b} \cdot e^{-\psi_{2}\left(d_{t}-\bar{d}\right) / Y_{t}} \cdot E_{t}\left\{\frac{\lambda_{t+1}^{o}}{\pi_{t+1}}\right\},
\end{aligned}
$$

where $\lambda_{t}^{o}$ is the Lagrange multiplier on equation (3) and $Q_{t} \cdot \lambda_{t}^{o}$ is the Lagrange multiplier on equation (4). Therefore, $\lambda_{t}^{o}$ represents the marginal utility of real income, whereas $Q_{t}$ represents the shadow real price of a unit of physical capital, i.e. Tobin's $Q$. Optimality additionally requires that the No-Ponzi condition on wealth is satisfied, which we assume to hold henceforth. 


\subsubsection{Non-Ricardian households}

As non-Ricardian households can neither save nor borrow, their budget constraint simplifies to

$$
\left(1+\tau_{t}^{c}\right) c_{t}^{r}=\left(1-\tau_{t}^{w}\right)\left(w_{t}^{p} n_{t}^{p, r}+w_{t}^{g} n_{t}^{g, r}\right)+\left(1-n_{t}^{p, r}-n_{t}^{g, r}\right) \kappa^{B},
$$

which determines rule-of-thumb consumption, $c_{t}^{r}$. The corresponding marginal utility of consumption for rule-of-thumb households is, thus, given from maximizing (1) for $i=r$ subject to (2) and (10), that is,

$$
\lambda_{t}^{r}=\frac{\left[c_{t}^{r}-h \cdot c_{t-1}^{r}\right]^{-\sigma_{c}}-\beta \cdot h \cdot E_{t}\left\{\left[c_{t+1}^{r}-h \cdot c_{t}^{r}\right]^{-\sigma_{c}}\right\}}{\left(1+\tau_{t}^{c}\right)}
$$

\subsubsection{Aggregation}

Given the above description, consumption per capita in the home country equals the weighted average of consumption for each household type, i.e.

$$
C_{t}=(1-\mu) \cdot c_{t}^{o}+\mu \cdot c_{t}^{r} .
$$

For future reference, per capita domestic demand for the home country's and the foreign country's consumption good equal

$$
\begin{aligned}
& C_{A t}=(1-\mu) c_{A t}^{o}+\mu c_{A t}^{r}, \\
& C_{B t}=(1-\mu) c_{B t}^{o}+\mu c_{B t}^{r},
\end{aligned}
$$

respectively. For the quantity variables that exclusively concern optimizing households, per capita amounts are given simply by

$$
\begin{aligned}
k_{t} & =(1-\mu) k_{t}^{o}, \\
\frac{B_{t}}{P_{t}} & =(1-\mu) \frac{B_{t}^{o}}{P_{t}}, \\
I_{t} & =(1-\mu) I_{t}^{o}, \\
D_{t} & =(1-\mu) D_{t}^{o}, \\
I_{A t} & =(1-\mu) I_{A t}^{o}, \\
I_{B t} & =(1-\mu) I_{B t}^{o},
\end{aligned}
$$

Employment aggregation will be described in the labor market section.

\subsection{Production}

The retail and intermediate goods sectors of the economy are similar to Smets and Wouters $(2003,2007)$ or Christiano et al. (2005), with the exception that labor services are not hired directly from the households but from a sector of firms that produce homogenous labor services in the manner of Christoffel at al. (2009) or de Walque et al. (2009). It is the latter firms that hire workers and bargain over wages with them. In this subsection, we focus on 
the retail and intermediate goods sectors, postponing the description of the labor market to the next subsection.

\subsubsection{Retailers}

There is a measure- $\omega$ continuum of firms in the retail (or final good) sector. Each retail firm purchases a variety of differentiated intermediate goods, bundle these into a final good and sell the latter under perfect competition. We assume that the law of one price holds within the union, which means that the price of the home country's final good is the same in both countries and equal to $P_{A t}$. The maximization problem of the representative retail firm reads

$$
\max _{\left\{\tilde{y}_{t}(j): j \in[0, \omega]\right\}} P_{A t} Y_{t}-\int_{0}^{\omega} P_{A t}(j) \tilde{y}_{t}(j) d j
$$

where

$$
Y_{t}=\left(\int_{0}^{\omega}\left(\frac{1}{\omega}\right)^{1 / \epsilon} \tilde{y}_{t}(j)^{(\epsilon-1) / \epsilon} d j\right)^{\epsilon /(\epsilon-1)}, \epsilon>1,
$$

is the retailer's production function, $\tilde{y}_{t}(j)$ is the retailer's demand for each differentiated input $j \in[0, \omega]$, and $P_{A t}(j)$ is the nominal price of each input. The first-order condition for each input $j \in[0, \omega]$ reads

$$
\tilde{y}_{t}(j)=\left(\frac{P_{A t}(j)}{P_{A t}}\right)^{-\epsilon} \frac{Y_{t}}{\omega} .
$$

Combining the latter with (13) and the zero profit condition, we obtain that the producer price index in the home country must equal

$$
P_{A t}=\left(\int_{0}^{\omega} \frac{1}{\omega} P_{A t}(j)^{1-\epsilon} d j\right)^{1 /(1-\epsilon)} .
$$

Notice that, since there are $\omega$ retail firms, total demand for each intermediate input equals

$$
\omega \tilde{y}_{t}(j) \equiv y_{t}(j)=\left(\frac{P_{A t}(j)}{P_{A t}}\right)^{-\epsilon} Y_{t}
$$

\subsubsection{Intermediate goods}

Firms in the intermediate goods sector have mass $\omega$. Each producer $j \in[0, \omega]$ operates the following technology,

$$
y_{t}(j)=\epsilon^{a} \cdot\left(k_{t-1}^{g}\right)^{\eta} \cdot\left[\tilde{k}_{t}(j)\right]^{\alpha} \cdot\left[l_{t}(j)\right]^{(1-\alpha)},
$$

where $\alpha \in[0,1]$ is the elasticity of output with respect to private capital, $l_{t}(j)$ denotes the demand for labor services, $\tilde{k}_{t}(j)$ is the demand for capital services and $\epsilon^{a}$ is TFP. Also, $k_{t-1}^{g}$ is the public capital stock available in period $t$, which is determined by the government and is assumed to be productivity-enhancing; the parameter $\eta \in[0,1)$ measures how influential public capital is on private production (see Leeper et al., 2010, for a discussion). Intermediate goods firms acquire labor and capital services in perfectly competitive factor markets at real (CPI-deflated) prices $x_{t}$ and $r_{t}^{k}$, respectively. In period $t$, the real profits of firm $j$ are thus 
given by

$$
\frac{P_{A t}(j)}{P_{t}} y_{t}(j)-x_{t} \cdot l_{t}(j)-r_{t}^{k} \cdot \tilde{k}_{t}(j)
$$

Cost minimization subject to (17) implies the following factor demand conditions,

$$
\begin{gathered}
r_{t}^{k}=m c_{t} \cdot \alpha \cdot \frac{y_{t}(j)}{\tilde{k}_{t}(j)}, \\
x_{t}=m c_{t} \cdot(1-\alpha) \cdot \frac{y_{t}(j)}{l_{t}(j)},
\end{gathered}
$$

where $m c_{t}$ is the real (CPI-deflated) marginal cost common to all intermediate good producers. ${ }^{4}$

We assume that intermediate goods firms set nominal prices à la Calvo (1983). Each period, a randomly chosen fraction $\theta_{P} \in[0,1)$ of firms cannot re-optimize their price. A firm that has the chance to reoptimize its price in period $t$ chooses the nominal price $P_{A t}(j)$ that maximizes

$$
E_{t} \sum_{k=0}^{\infty}\left(\beta \theta_{P}\right)^{k} \frac{\lambda_{t+k}^{o}}{\lambda_{t}^{o}}\left[\frac{P_{A t}(j)}{P_{t+k}}-m c_{t+k}\right] y_{t+k}(j),
$$

subject to $y_{t+k}(j)=\left(P_{A t}(j) / P_{A t+k}\right)^{-\epsilon} Y_{t+k}$. The first-order condition is given by

$$
E_{t} \sum_{k=0}^{\infty}\left(\beta \theta_{P}\right)^{k} \frac{\lambda_{t+k}^{o}}{\lambda_{t}^{o}}\left[\frac{\tilde{P}_{A t}}{P_{t+k}}-\frac{\epsilon}{\epsilon-1} m c_{t+k}\right]\left(\frac{\tilde{P}_{A t}}{P_{A t+k}}\right)^{-\epsilon} Y_{t+k}=0,
$$

where $\tilde{P}_{A t}$ is the optimal price chosen by all period-t price setters. The law of motion of the price level is given by

$$
P_{A t}=\left[\theta_{P}\left(P_{A t-1}\right)^{1-\epsilon}+\left(1-\theta_{P}\right)\left(\tilde{P}_{A t}\right)^{1-\epsilon}\right]^{1 /(1-\epsilon)},
$$

or equivalently,

$$
1=\theta_{P}\left(\frac{1}{\pi_{A t}}\right)^{1-\epsilon}+\left(1-\theta_{P}\right) \tilde{p}_{t}^{1-\epsilon},
$$

where $\tilde{p}_{t} \equiv \tilde{P}_{A t} / P_{A t}$ is the relative (PPI-deflated) optimal price.

\subsection{The labor market}

Labor firms hire workers from the household sector in order to produce homogenous labor services, which they sell to intermediate goods producers at the perfectly competitive price $x_{t}$. This modelling strategy follows Christoffel et al. (2009) or de Walque et al. (2009). We

\footnotetext{
${ }^{4}$ Notice that constant returns to scale in private capital and labor, together with perfectly competitive input prices, imply that the ratios $y_{t}(j) / \tilde{k}_{t}(j)$ and $y_{t}(j) / l_{t}(j)$ are equalized across firms. Combining (17), (19) and
} (20), the common real marginal cost can be expressed as

$$
m c_{t}=\frac{1}{\epsilon^{a} \cdot\left(k_{t-1}^{g}\right)^{\eta}} \cdot\left(\frac{x_{t}}{1-\alpha}\right)^{1-\alpha} \cdot\left(\frac{r_{t}^{k}}{\alpha}\right)^{\alpha} .
$$


keep the conventional assumption of the Pissarides (2000) framework that each labor firm can at most hire one worker. The production function of each labor firm is linear in the number of hours worked by its employee, which is fixed at the level $\bar{h}$. Letting $N_{t}^{p}$ denote both the fraction of the labor force employed in the private sector and the per-capita number of labor firms, the total per-capita supply of labor services is given by

$$
L_{t}=N_{t}^{P} \cdot \bar{h}
$$

Equilibrium in the market for labor services requires that $\omega L_{t}=\int_{0}^{\omega} l_{t}(j) d j$. Using equations (16) and (17), together with the fact that the capital-labor ratio is equalized across intermediate goods firms $\left(\tilde{k}_{t}(j) / l_{t}(j)=k_{t-1} / L_{t}\right.$ for all $\left.j\right)$, the above condition can be expressed as

$$
Y_{t} D_{t}=\epsilon^{a}\left(k_{t-1}^{g}\right)^{\eta} k_{t-1}^{\alpha} L_{t}^{1-\alpha},
$$

where $D_{t} \equiv \int_{0}^{\omega} \omega^{-1}\left(P_{A t}(j) / P_{A t}\right)^{-\epsilon} d j$ is a measure of price dispersion. In what follows, we will specify the matching process and flows in the labor market, vacancy creation and (private) wage determination. Government wages and employment are autonomously chosen by the fiscal authority (see section 2.4).

\subsubsection{Matching process and labor market flows}

As already described, we consider a model in which the worker can be in one of three states: (i) unemployed, (ii) employed in the public sector, or (iii) employed in the private sector. Unemployment is the residual state in the sense that a worker whose employment relationship ends flows back into unemployment. Unemployed workers look for job opportunities. They find them either in the public sector (with superscript $g$ for government employment) or in the private sector (with superscript $p$ ). Workers do not direct search to either the public or the private sector and are, thus, matched randomly. In this sense, the matching process differs slightly from other papers incorporating public employment in a matching framework (as, for example, Quadrini and Trigari, 2007; Afonso and Gomes, 2008; or Gomes, 2009). We apply the three state labor market structure of, for example, Albrecht et al. (2009). While we follow this approach for simplicity, it should be noted that this assumption does not affect the results qualitatively.

Let us denote sector-specific per capita employment in period $t$ by $N_{t}^{f}$, where $f=$ $p, g$ stands for private and public (i.e. government) employment, respectively. ${ }^{5}$ The total employment rate is then given by $N_{t}^{t o t}=N_{t}^{p}+N_{t}^{g}$, while the unemployment rate is given by

$$
U_{t}=1-N_{t}^{t o t}
$$

Following Blanchard and Gali (2010), we assume that the hiring round takes place at the beginning of each period, and that new hires start producing immediately. We also assume that

\footnotetext{
${ }^{5}$ Note that, as we work with household type-specific (un)employment rates for each sector in the households' budget constraints (see equations (3) and (10)), we basically have to aggregate employment in order to obtain total (per capita) employment levels across public and private employment. This is done in an analogously to the aggregation of consumption decisions (see section 2.1.3; again implying that capital letters indicate aggregate levels). Thus, aggregated per capita employment levels in each sector are given by $N_{t}^{f}=(1-\mu)$. $n_{t}^{f, o}+\mu \cdot n_{t}^{f, r}$. Noting that dismissal and job-finding probabilities are equal across household types, we have that $N_{t}^{f}=n_{t}^{f, o}=n_{t}^{f, r}$; see also Moyen and Stähler (2009) for details.
} 
workers dismissed at the end of period $t-1$ start searching for a new job at the beginning of period $t$. Therefore, the pool of searching workers at the beginning of period $t$ is given by

$$
\tilde{U}_{t}=U_{t-1}+s^{p} N_{t-1}^{p}+s^{g} N_{t-1}^{g} .
$$

The matching process is governed by a standard Cobb-Douglas aggregate matching function for each sector $f=p, g$,

$$
M_{t}^{f}=\kappa_{e}^{f} \cdot\left(\tilde{U}_{t}\right)^{\varphi^{f}} \cdot\left(v_{t}^{f}\right)^{\left(1-\varphi^{f}\right)},
$$

where $\kappa_{e}^{f}>0$ is the sector-specific matching efficiency parameter, $\varphi^{f} \in(0,1)$ the sectorspecific matching elasticity and $M_{t}^{f}$ the number of new matches formed in period $t$ resulting from the total number of searchers and the number of sector-specific vacancies $v_{t}^{f}{ }^{6}$ The probability for an unemployed worker to find a job in sector $f$ can thus be stated as $p_{t}^{f}=$ $M_{t}^{f} / \tilde{U}_{t}$, while the probability of filling a vacancy is given by $q_{t}^{f}=M_{t}^{f} / v_{t}^{f}$. We assume a constant separation rate in each sector, denoted by $s^{f}$. The law of motion for sector-specific employment rates is therefore given by

$$
N_{t}^{f}=\left(1-s^{f}\right) \cdot N_{t-1}^{f}+p_{t}^{f} \cdot \tilde{U}_{t}
$$

for $f=g, p$. Thus, employment in sector $f$ today is given by yesterday's employment that has not been destroyed plus newly created matches in that sector.

\subsubsection{Asset value of jobs and wage bargaining}

Because of search frictions, formed matches entail economic rents. Firms and workers bargain about their share of the overall match surplus. In order to describe the bargaining process we first have to derive the asset value functions for workers and firms. We assume staggered bargaining of nominal wages along the lines of Bodart et al. (2006). In particular, each period a randomly chosen fraction $\theta_{w}$ of continuing firms cannot renegotiate wages, while a fraction $\theta_{w}^{n}$ of newly created firms does not bargain over wages and simply pays the average nominal wage of the previous period. Letting $\tilde{W}_{t}^{p}$ denote the nominal wage negotiated in period $t$, the value function of a firm that renegotiates in that period is given by

$$
\begin{aligned}
J_{t}\left(\tilde{W}_{t}^{p}\right)= & E_{t} \sum_{k=0}^{\infty}\left\{\left[\beta \cdot\left(1-s^{p}\right) \cdot \theta_{w}\right]^{k} \cdot \frac{\lambda_{t+k}^{o}}{\lambda_{t}^{o}} \cdot\left[\bar{h} \cdot x_{t+k}-\left(1+\tau_{t+k}^{s c}\right) \cdot \frac{\tilde{W}_{t}^{p}}{P_{t+k}}\right]\right\} \\
& +\left(1-\theta_{w}\right) \cdot E_{t} \sum_{k=1}^{\infty}\left\{\left[\beta \cdot\left(1-s^{p}\right)\right]^{k} \cdot \theta_{w}^{k-1} \cdot \frac{\lambda_{t+k}^{o}}{\lambda_{t}^{o}} \cdot J_{t+k}\left(\tilde{W}_{t+k}^{p}\right)\right\},
\end{aligned}
$$

where $\tau_{t}^{s c}$ is the social security contribution rate. Therefore, the value of the firm is the discounted profit flow in those future states in which it is not allowed to renegotiate (the term on the right-hand side in the first line of equation 28), plus its continuation value should

\footnotetext{
${ }^{6}$ Note that, with the representation above (equation (26)), we are able to calibrate the matching functions across sectors differently. In the case $\varphi^{g}<\varphi^{p}$ (the strategy which we will follow), vacancies are relatively more important than the pool of unemployment in the government sector. We believe this is a plausible assumption.
} 
it have the chance to reoptimize in the next period (the term in the second line). ${ }^{7}$ For new jobs where firm and worker do not bargain, the nominal wage equals last period's average nominal wage, $W_{t-1}^{p}$, and the value of the job equals

$$
J_{t}\left(W_{t-1}^{p}\right)=J_{t}\left(\tilde{W}_{t}^{p}\right)-E_{t} \sum_{k=0}^{\infty}\left\{\left[\beta \cdot\left(1-s^{p}\right) \cdot \theta_{w}\right]^{k} \cdot \frac{\lambda_{t+k}^{o}}{\lambda_{t}^{o}} \cdot\left(1+\tau_{t+k}^{s c}\right) \cdot \frac{W_{t-1}^{p}-\tilde{W}_{t}^{p}}{P_{t+k}}\right\} .
$$

Opening a vacancy has a real (CPI-deflated) flow cost of $\kappa_{v}^{p}$. Following Pissarides (2009), we assume that upon matching the firm incurs a training cost, denoted by $\kappa_{t c}$. Free entry into the vacancy posting market drives the expected value of a vacancy to zero. Under our assumption of instantaneous hiring, real vacancy posting costs, $\kappa_{v}^{p}$, must equal the time$t$ vacancy filling probability, $q_{t}^{p}$, times the expected value of a filled job in period $t$ net of training costs. The latter condition can be expressed as

$$
\frac{\kappa_{v}^{p}}{q_{t}^{p}}+\kappa_{t c}=\left(1-\theta_{w}^{n}\right) \cdot J_{t}\left(\tilde{W}_{t}^{p}\right)+\theta_{w}^{n} \cdot J_{t}\left(W_{t-1}^{p}\right)
$$

where we take into account that the wage of the newly-created job may be optimally bargained with probability $1-\theta_{w}^{n}$.

We can now derive the asset value functions of workers. In particular, we are interested in the value of the job in excess of the value of being unemployed, i.e. the worker's match surplus. Since different household types use different stochastic discount factors, we must distinguish between the surplus for an optimizing and a rule-of-thumb household. For a worker belonging to a type- $i$ household, the surplus value of a job in a renegotiating firm is given by

$$
\begin{aligned}
H_{t}^{i, p}\left(\tilde{W}_{t}^{p}\right)= & E_{t} \sum_{k=0}^{\infty}\left\{\left[\beta \cdot\left(1-s^{p}\right) \cdot \theta_{w}\right]^{k} \cdot \frac{\lambda_{t+k}^{i}}{\lambda_{t}^{i}} \cdot\left[\left(1-\tau_{t+k}^{w}\right) \cdot \frac{\tilde{W}_{t}^{p}}{P_{t+k}}-o o_{t+k}^{i, p}\right]\right\} \\
& +\left(1-\theta_{w}\right) \cdot E_{t} \sum_{k=1}^{\infty}\left\{\left[\beta \cdot\left(1-s^{p}\right)\right]^{k} \cdot \theta_{w}^{k-1} \cdot \frac{\lambda_{t+k}^{i}}{\lambda_{t}^{i}} \cdot H_{t+k}^{i, p}\left(\tilde{W}_{t+k}^{p}\right)\right\},
\end{aligned}
$$

for $i=o, r$, where

$$
\begin{aligned}
o o_{t}^{i, f} \equiv & \kappa^{B}+\beta\left(1-s^{f}\right) E_{t} \frac{\lambda_{t+1}^{i}}{\lambda_{t}^{i}}\left\{p_{t+1}^{g} H_{t+1}^{i, g}\right. \\
& \left.+p_{t+1}^{p}\left[\left(1-\theta_{w}^{n}\right) H_{t+1}^{i, p}\left(\tilde{W}_{t+1}^{p}\right)+\theta_{w}^{n} H_{t+1}^{i, p}\left(W_{t}^{p}\right)\right]\right\}
\end{aligned}
$$

represents the outside option of a type- $i$ worker employed in sector $f=p, g$ at time $t$. The latter is the sum of unemployment benefits, $\kappa^{B}$, and the expected value of searching for a job in the following period, where $p_{t+1}^{f}$ is the probability of finding a job in sector $f=p, g$. Conditional on landing on a private-sector job $(f=p)$, the surplus value for the worker is contingent on whether the firm is allowed to bargain (in which case the worker receives $\tilde{W}_{t+1}^{p}$ ) or not (in which case she receives today's average wage, $W_{t}^{p}$ ). In new jobs where the

\footnotetext{
${ }^{7}$ Details on how to derive equation (28) can be found in Christoffel et al. (2009) and de Walque et al. (2009) or sent upon request. An analogous proceeding holds for the workers' side described below.
} 
wage is not optimally bargained, the surplus value enjoyed by type- $i$ workers is given by

$$
H_{t}^{i, p}\left(W_{t-1}^{p}\right)=H_{t}^{i, p}\left(\tilde{W}_{t}^{p}\right)+E_{t} \sum_{k=0}^{\infty}\left\{\left[\beta \cdot\left(1-s^{p}\right) \cdot \theta_{w}\right]^{k} \cdot \frac{\lambda_{t+k}^{i}}{\lambda_{t}^{i}} \cdot\left(1-\tau_{t+k}^{w}\right) \cdot \frac{W_{t-1}^{p}-\tilde{W}_{t}^{p}}{P_{t+k}}\right\} .
$$

Let $H_{t}^{i, g}$ denote the surplus value of a government job for a type-i worker. As wages there are autonomously set by the fiscal authority, the asset value function simplifies to

$$
H_{t}^{i, g}=\left(1-\tau_{t}^{w}\right) w_{t}^{g}-o o_{t}^{i, g}+\beta\left(1-s^{g}\right) E_{t}\left\{\frac{\lambda_{t+1}^{i}}{\lambda_{t}^{i}} \cdot H_{t+1}^{i, g}\right\}
$$

where $w_{t}^{g}$ is the real wage paid by the government. The only influence of staggered wage setting in the private sector on the asset value of public employees operates through the outside option of public sector workers, $o o_{t}^{i, g}$, given by (31) for $f=g$. Given the asset value functions of firms and workers, we are now in a position to describe the wage bargaining game.

As already mentioned above, we assume unionized wage bargaining following Boscá et al. (2009a, 2009b, 2010). ${ }^{8}$ The unions's utility is the average utility of its members. More precisely, it is the weighted average of the surplus of optimizing and rule-of-thumb workers, which we denote by

$$
\Omega_{t} \equiv(1-\mu) H_{t}^{o, p}\left(\tilde{W}_{t}^{p}\right)+\mu H_{t}^{r, p}\left(\tilde{W}_{t}^{p}\right) .
$$

This implies that the union wants to maximize its members' gain from employment over unemployment, as in the formulation by Oswald (1993). We assume Nash bargaining between the firm and the union, where the union's bargaining power parameter is given by $\xi \in[0,1)$. The joint maximization problem is, therefore,

$$
\max _{\tilde{W}_{t}^{p}}\left[\Omega_{t}\right]^{\tilde{\xi}}\left[J_{t}\left(\tilde{W}_{t}^{p}\right)\right]^{1-\xi} .
$$

The resulting sharing rule is given by

$$
\Omega_{t}=\frac{\xi}{1-\xi} \cdot \frac{E_{t} \sum_{0}^{\infty}\left\{\left((1-\mu) \frac{\lambda_{t+k}^{o}}{\lambda_{t}^{o}}+\mu \frac{\lambda_{t+k}^{r}}{\lambda_{t}^{r}}\right)\left[\beta\left(1-s^{p}\right) \theta_{w}\right]^{k} \frac{\left(1-\tau_{t+k}^{w}\right)}{P_{t+k}}\right\}}{E_{t} \sum_{0}^{\infty}\left\{\frac{\lambda_{t+k}^{o}}{\lambda_{t}^{o}}\left[\beta\left(1-s^{p}\right) \theta_{w}\right]^{k} \frac{\left(1+\tau_{t+k}^{s c}\right)}{P_{t+k}}\right\}} \cdot J_{t}\left(\tilde{W}_{t}^{p}\right),
$$

which states that the share of the matching surplus the worker receives depends on the union's bargaining power and (the expected evolution of) labor income taxes, prices and household type-specific stochastic discount factors. Solving equation (34) for $\tilde{W}_{t}^{p}$ by using the corresponding asset value functions gives the optimal wage bargained in period $t$. Finally, we derive the average real wage in the private sector, $w_{t}^{p} \equiv W_{t}^{p} / P_{t}$. The latter evolves

\footnotetext{
${ }^{8}$ Assuming individual bargaining between each worker with the firm does not change the steady-state results at all. But it (slightly) changes the magnitude of wage evolution across the cycle. This is due to the fact that rule-of-thumb households discount differently. The effects are very small, however, and, therefore, we decided to stick to the assumptions made by Boscá et al. (2009a, 2009b, 2010).
} 
according to

$$
w_{t}^{p}=\frac{\left(1-s^{p}\right) N_{t-1}^{p}}{N_{t}^{p}}\left[\left(1-\theta_{w}\right) \tilde{w}_{t}^{p}+\theta_{w} \cdot \frac{w_{t-1}^{p}}{\pi_{t}}\right]+\frac{M_{t}^{P}}{N_{t}^{p}}\left[\left(1-\theta_{w}^{n}\right) \tilde{w}_{t}^{p}+\theta_{w}^{n} \cdot \frac{w_{t-1}^{p}}{\pi_{t}}\right],
$$

where $\tilde{w}_{t}^{p} \equiv \tilde{W}_{t}^{p} / P_{t}$ is the real optimally bargained wage, $w_{t-1}^{p} / \pi_{t}=W_{t-1}^{p} / P_{t}$ is the real value of yesterday's average nominal wage at today's prices, and we have taken into account the fact that new and continuing jobs pay the optimally bargained wage with probabilities $1-\theta_{w}^{n}$ and $1-\theta_{w}$, respectively. Equation (35) can also be expressed as $w_{t}^{p}=\left(1-\gamma_{t}\right) \tilde{w}_{t}^{p}+$ $\gamma_{t} \cdot w_{t-1}^{p} / \pi_{t}$, where $\gamma_{t} \equiv \theta_{w}+\left(M_{t}^{p} / N_{t}^{p}\right) \cdot\left(\theta_{w}^{n}-\theta_{w}\right)$ (see also Blanchard and Galí, 2007, who propose a similar equation for real wage rigidity).

\subsection{Fiscal authorities}

The real (CPI-deflated) per capita value of end-of-period government debt, $b_{t} \equiv B_{t} / P_{t}$, evolves according to a standard debt accumulation equation,

$$
b_{t}=\frac{R_{t-1}}{\pi_{t}} b_{t-1}+P D_{t}
$$

where $P D_{t}$ denotes real (CPI-deflated) per capita primary deficit. The latter is given by per capita fiscal expenditures minus per capita fiscal revenues,

$$
\begin{aligned}
P D_{t}= & {\left[\frac{G_{t}}{p_{B t}^{1-\omega-\psi}}+\kappa^{B} U_{t}+S u b_{t}\right] } \\
& -\left[\left(\tau_{t}^{w}+\tau_{t}^{s c}\right)\left[w_{t}^{p} N_{t}^{P}+w_{t}^{g} N_{t}^{g}\right]+\tau_{t}^{b} \frac{R_{t-1}-1}{\pi_{t}} b_{t-1}\right. \\
& \left.+\tau_{t}^{c} C_{t}+\tau_{t}^{k}\left(r_{t}^{k}-\delta^{k}\right) k_{t-1}+T_{t}\right]
\end{aligned}
$$

where $G_{t}$ denotes per capita government spending in goods and services expressed in PPI terms (hence the correction for the CPI-to-PPI ratio, $P_{t} / P_{A t}=p_{B t}^{1-\omega-\psi}$ ). Government spending in goods and services is in turn the sum of government demand for privatelyproduced consumption and investment goods (which we will henceforth refer to as 'public purchases' and 'public investment', respectively) and the public sector wage bill (gross of social security contributions). Following standard practice, we assume full home-bias in public purchases and public investment, such that their nominal price is equal to the home country PPI, $P_{A t} \cdot{ }^{9}$ Letting $C_{t}^{g}$ and $I_{t}^{g}$ denote real per capita public purchases and public investment, respectively, we have the following nominal relationship: $P_{A t} G_{t}=$ $P_{A t}\left(C_{t}^{g}+I_{t}^{g}\right)+\left(1+\tau_{t}^{s c}\right) P_{t} w_{t}^{g} N_{t}^{g}$. Dividing by $P_{A t}$ and using $P_{t} / P_{A t}=p_{B t}^{1-\omega-\psi}$, we obtain

$$
G_{t}=C_{t}^{g}+I_{t}^{g}+\left[\left(1+\tau_{t}^{s \mathcal{C}}\right) w_{t}^{g} N_{t}^{g}\right] p_{B t}^{1-\omega-\psi} .
$$

\footnotetext{
${ }^{9}$ Full home bias in public consumption and investment is assumed for simplicity and can be justified by the fact that, for OECD countries, there is evidence for strong home bias in government procurement, much over and above that observed in private consumption (see, for example, Trionfetti, 2000; and Brulhart and Trionfetti, 2004).
} 
Given public investment, the stock of public physical capital evolves as follows,

$$
k_{t}^{g}=\left(1-\delta^{g}\right) k_{t-1}^{g}+I_{t}^{g},
$$

where we assume that the public capital stock depreciates at rate $\delta^{g}$ (which may potentially deviate from the private-sector depreciation rate).

The government therefore has six instruments on the revenue side: the tax rate on wage income, $\tau_{t}^{w}$, on consumption, $\tau_{t}^{c}$, on bond returns, $\tau_{t}^{b}$, on capital returns, $\tau_{t}^{k}$, the social security contribution tax rate, $\tau_{t}^{s c}$, and lump-sum taxes, $T_{t}$. It also has five instruments on the expenditures side: public purchases, $C_{t}^{g}$, public investment, $I_{t}^{g}$, public sector wages, $w_{t}^{g}$, public employment, $N_{t}^{g}$, and lump-sum subsidies, $S u b_{t}$. For the tax rates, we assume a rule of the form

$$
X_{t}=\bar{X}+\rho_{X}\left(X_{t-1}-\bar{X}\right)+\left(1-\rho_{X}\right) \phi_{X} \cdot e_{X}^{a u x} \cdot\left(\frac{b_{t-1}}{Y_{t-1}^{t o t}} p_{B t-1}^{1-\omega-\psi}-\omega^{b}\right)+\epsilon_{t}^{X},
$$

for $X \in\left\{\tau^{w}, \tau^{s c}, \tau^{b}, \tau^{c}, \tau^{k}\right\}$, whereas for all other instruments the assumed rule is

$$
\frac{X_{t}}{\bar{X}}=\left(\frac{X_{t-1}}{\bar{X}}\right)^{\rho_{X}} \cdot\left(\frac{b_{t-1}}{\omega^{b} Y_{t-1}^{t o t}} p_{B t-1}^{1-\omega-\psi}\right)^{\left(1-\rho_{X}\right) \phi_{X}} \cdot \exp \left(\epsilon_{t}^{X}\right),
$$

for $X \in\left\{C^{g}, I^{g}, w^{g}, N^{g}, S u b, T\right\}$, where $\bar{X}$ denotes the corresponding long-run target, $\rho_{X}$ the smoothing parameter, $b_{t-1} p_{B t-1}^{1-\omega-\psi} / Y_{t-1}^{t o t}$ is the ratio of public debt over GDP in period $t-1$ (the home country's per capita GDP in terms of PPI, $Y_{t}^{\text {tot }}$, is defined later), $\omega^{b}$ is a long-run target for the debt ratio, $\phi_{X}$ measures the responsiveness of the corresponding instrument to deviations in the debt ratio from its long-run target, and the $\epsilon_{t}^{X}$ is an iid shock. $e_{X}^{a u x}$ is an exogenous auxiliary variable for simulation purposes. We assume $e_{X}^{a u x}=1$ unless explicitly specified differently. For $C_{t}^{g}$ and $I_{t}^{g}$, the long-run target is a certain weight of steady-state GDP: $\bar{C}^{g}=\omega_{C g} \bar{Y}^{\text {tot }}, \bar{I}^{g}=\omega_{I G} \bar{Y}^{\text {tot }}$. For public sector wages and employment, the long-run targets are, respectively, a premium over private-sector wages and a share of total employment in the steady state: $\bar{w}^{g}=\omega_{w g} \bar{w}^{p}, \bar{N}^{g}=\omega_{n g} \bar{N}^{t o t}$. In order to guarantee stability in the debt ratio, for at least one instrument the coefficient $\phi_{X}$ must be non-zero (positive for revenue instruments, negative for expenditure instruments). Notice however that it generally suffices to assume a small and inertial responsiveness of the chosen instrument(s) to deviations in the debt ratio. ${ }^{10}$

\footnotetext{
${ }^{10}$ The literature on optimal fiscal policy derives two stylized results. First, it seems preferable to move fiscal instruments by a small amount permanently to service a new higher level of debt, rather than change them by a large amount on a temporary basis to return debt to its initial level (see, for example, Schmitt-Grohé and Uribe, 2007, Kirsanova and Wren-Lewis, 2007, and Canzoneri et al., 2008, among others). This finding can be related to the tax smoothing argument (see Barro, 1979, and Lucas and Stokey, 1983). Second, mild countercyclical policy responses have a stabilizing and welfare-enhancing effect (see also Leith and WrenLewis, 2007, Straub and Tchakarov, 2007, or Galí and Monacelli, 2008).
} 


\subsection{The foreign country block, international linkages and union-wide monetary policy}

In this section, we will describe some structural relationships corresponding to the foreign country block, point out the international linkages via trade in goods and foreign assets, and describe the union-wide monetary policy rule.

\subsubsection{The foreign country}

We use asterisks to denote decisions made by foreign agents as well as structural parameters in the foreign country. The latter is modelled analogously to the home country. For this reason, here we discuss only some structural relationships, while the full set of equations corresponding to the foreign country is analogous to the home country (a full equation summary is available upon request).

The consumption basket of foreign households is given by

$$
c_{t}^{i *}=\left(\frac{c_{A t}^{i *}}{\omega-\psi^{*}}\right)^{\omega-\psi^{*}}\left(\frac{c_{B t}^{i *}}{1-\omega+\psi^{*}}\right)^{1-\omega+\psi^{*}},
$$

for $i=o, r$, where $c_{A t}^{i *}$ and $c_{B t}^{i *}$ denote consumption by foreign type- $i$ households of goods produced in country A (home) and B (foreign), respectively, while $\psi^{*}$ captures the degree of home bias in foreign households' preferences. The foreign country's investment basket is analogously defined. The corresponding consumer price index in the foreign country (which is used as numeraire by households and firms in that country) is given by

$$
P_{t}^{*}=P_{A t}^{\omega-\psi^{*}} P_{B t}^{1-\omega+\psi^{*}}=P_{B t}\left(\frac{1}{p_{B t}}\right)^{\omega-\psi^{*}} .
$$

Therefore, the foreign country's before-VAT consumer price inflation evolves according to

$$
\pi_{t}^{*} \equiv \frac{P_{t}^{*}}{P_{t-1}^{*}}=\pi_{B t}\left(\frac{p_{B t-1}}{p_{B t}}\right)^{\omega-\psi^{*}},
$$

where $\pi_{B t} \equiv P_{B t} / P_{B t-1}$ is producer price inflation in the foreign country. The PPI itself evolves according to

$$
\begin{aligned}
P_{B t} & =\left(\int_{0}^{1-\omega} \frac{1}{1-\omega} P_{B t}(j)^{1-\epsilon^{*}} d j\right)^{1 /\left(1-\epsilon^{*}\right)} \\
& =\left[\theta_{P}^{*}\left(\pi_{t-1}^{\gamma_{P}^{*}} \cdot P_{B t-1}\right)^{1-\epsilon^{*}}+\left(1-\theta_{P}^{*}\right)\left(\tilde{P}_{B t}\right)^{1-\epsilon^{*}}\right]^{1 /\left(1-\epsilon^{*}\right)},
\end{aligned}
$$

where $\tilde{P}_{B t}$ is the common nominal price chosen by the foreign country's price-setters in period $t$. Also, the nominal interest rate paid/received by the foreign country's nationals on international bonds equals $R_{t}^{e c b} \exp \left(-\psi_{d}\left(d_{t}^{*}-\bar{d}^{*}\right) / Y_{t}^{*}\right)$, where $(-) d_{t}^{*} / Y_{t}^{*}$ is the foreign country's ratio of net foreign debt over output. 


\subsubsection{International linkages}

As already mentioned, international linkages between the two countries result from trade in goods and services as well as in international bonds. The home country's net foreign asset position, expressed in terms of PPI, evolves according to

$$
d_{t}=\frac{R_{t-1}^{e c b} \cdot e^{-\psi_{d}\left(d_{t-1}-\bar{d}\right) / Y_{t-1}}}{\pi_{A t}} \cdot d_{t-1}+\underbrace{\frac{1-\omega}{\omega}\left(C_{A t}^{*}+I_{A t}^{*}\right)-p_{B t}\left(C_{B t}+I_{B t}\right)}_{=\text {Trade balance }},
$$

where $(1-\omega)\left(C_{A t}^{*}+I_{A t}^{*}\right) / \omega$ are real per capita exports and $p_{B t}\left(C_{B t}+I_{B t}\right)$ are real per capita imports. Zero net supply of international bonds implies

$$
\omega d_{t}+(1-\omega) p_{t}^{B} d_{t}^{*}=0 .
$$

Finally, terms of trade $p_{B t}=P_{B t} / P_{A t}$ evolve according to

$$
p_{B t}=\frac{\pi_{B t}}{\pi_{A t}} p_{B t-1}
$$

\subsubsection{Equilibrium in goods markets and GDP}

Market clearing implies that private per capita production in the home and foreign country, $Y_{t}$ and $Y_{t}^{*}$ respectively, is used for private and public consumption as well as private and public investment demand,

$$
\begin{aligned}
Y_{t} & =C_{A t}+I_{A t}+C_{t}^{g}+I_{t}^{g}+\frac{1-\omega}{\omega}\left(C_{A t}^{*}+I_{A t}^{*}\right), \\
Y_{t}^{*} & =C_{B t}^{*}+I_{B t}^{*}+C_{t}^{g *}+I_{t}^{g *}+\frac{\omega}{1-\omega}\left(C_{B t}+I_{B t}\right) .
\end{aligned}
$$

Consistently with national accounting, each country's GDP is the sum of private-sector production and government production of goods and services. The latter is measured at input costs, that is, by the gross government wage bill. Let $Y_{t}^{t o t}$ and $Y_{t}^{t o t, *}$ denote real (PPI-deflated) per capita GDP in the home and foreign country, respectively. We then have

$$
\begin{gathered}
Y_{t}^{t o t}=Y_{t}+\left(1+\tau_{t}^{s c}\right) w_{t}^{g} N_{t}^{g} p_{B t}^{1-\omega-\psi}, \\
Y_{t}^{t o t, *}=Y_{t}^{*}+\left(1+\tau_{t}^{s c *}\right) w_{t}^{g *} N_{t}^{g *} p_{B t}^{-\left(\omega-\psi^{*}\right)},
\end{gathered}
$$

where in (45) we have used $P_{t}^{*} / P_{B t}=p_{B t}^{-\left(\omega-\psi^{*}\right)}$.

\subsubsection{Monetary authority}

We assume that the area-wide monetary authority has its nominal interest rate, $R_{t}^{e c b}$, respond to deviations of area-wide after-VAT CPI inflation from its long-run target, $\bar{\pi}$, and to area- 
wide GDP growth, according to a simple Taylor rule,

$$
\frac{R_{t}^{e c b}}{\bar{R}^{e c b}}=\left(\frac{R_{t-1}^{e c b}}{\bar{R}^{e c b}}\right)^{\rho_{R}}\left\{\left[\left(\frac{\pi_{t}^{\tau^{c}}}{\bar{\pi}^{\tau^{c}}}\right)^{\omega}\left(\frac{\pi_{t}^{\tau^{c}, *}}{\bar{\pi}^{\tau^{c}, *}}\right)^{1-\omega}\right]^{\phi_{\pi}}\left[\left(\frac{Y_{t}^{t o t}}{Y_{t-1}^{t o t}}\right)^{\omega}\left(\frac{Y_{t}^{t o t, *}}{Y_{t-1}^{t o t, *}}\right)^{1-\omega}\right]^{\phi_{y}}\right\}^{\left(1-\rho_{R}\right)},
$$

where $\rho_{R}$ is a smoothing parameter, $\phi_{\pi}$ and $\phi_{y}$ are the monetary policy's stance on inflation and output growth, respectively. This completes the model description. We now turn to the model calibration.

\subsection{Calibration}

We calibrate our model to quarterly frequency. We calibrate the home country $(A)$ to the Spanish economy and the foreign country $(B)$ to the rest of the European Monetary Union. We set the home country size to $\omega=0.10$, which roughly corresponds to Spain's population share in the EMU. The remaining parameters are calibrated as follows. Some parameters are chosen such that the model's deterministic steady state replicates a number of long-run targets in the data. These long-run targets are displayed in Tables 1 and 2 for the home (Spain) and foreign (rest of EMU) countries, respectively. The rest of the parameters are set according to microeconomic evidence as well as following the literature. A summary of all structural parameters can be found in Table 3. Unless explicitly stated differently, we assume a symmetric calibration between the home and foreign country. We note in passing that, given both the long-run targets and the parameters chosen according to micro data and literature, we are able to analytically solve for the model's deterministic steady state and for the parameter values consistent with the long-run targets.

\subsubsection{Steady-state ratios and targeted parameters}

We normalize per-capita GDP in both countries to one, i.e. $\bar{Y}=\bar{Y}^{\text {tot* }}=1$ implying the TFP scaling parameters $\epsilon^{a}$ and $\epsilon^{a *}$. For the steady-state ratios in the home and foreign country, we mainly refer to national accounts data from 1999 to 2008. The data comes from the European Commission (AMECO and Public Finance Report - 2010) and Eurostat (NEW CRONOS). From the data, we set the steady-state shares of different government spending-to-GDP ratios according to Table 1. Furthermore, the ratios of government-granted subsidies and public debt over GDP are set according to this data.

Regarding the tax rates, we have calculated them as average implicit tax rates according to the following procedure: we take the government revenues from a specific tax and divide it by its corresponding base. This is done for all tax rates except for Spain's personal income tax rate, $\bar{\tau}^{w}$ (which in the model includes social security contributions by workers), and the tax rate on returns from public debt $\bar{\tau}^{b}$ : the latter is set equal to the former, which in turn is based on calculations by Argimón et al. (2007) using Spanish fiscal micro data. ${ }^{11}$

According to Spain's Encuesta de Población Activa (EPA), an official labor force survey, the unemployment rate in Spain from 1999 to 2008 averaged $\bar{U}=11.13 \%$, while the fraction

\footnotetext{
${ }^{11}$ Hence, we ignore a tax reform of 2007 under which income from interest payments from public debt and similar instruments are separated from the rest of the taxpayer's tax base, and taxed at the marginal rate of $18 \%$. However, the implicit tax rate (including all kinds of reductions, deductions, etc.) is probably much lower, so it is sensible to set it equal to the personal income tax rate (as it was the case before 2007).
} 
Table 1: Targeted values (home country: Spain)

\begin{tabular}{lcc}
\hline Target & Symbol & Value \\
\hline PPI inflation & $\bar{\pi}_{A}$ & 1.0000 \\
Current account & $\bar{d}=-\bar{d}^{*}$ & 0.0000 \\
(Average) Labor income tax rate & $\bar{\tau}^{w}$ & 0.1622 \\
Bond tax rate & $\bar{\tau}^{b}$ & 0.1622 \\
VAT rate & $\bar{\tau}^{c}$ & 0.0762 \\
Social security contribution rate & $\bar{\tau}^{s \mathcal{C}}$ & 0.1555 \\
Capital tax rate & $\bar{\tau}^{k}$ & 0.1806 \\
Unemployment rate & $\bar{U}$ & 0.1113 \\
Fraction of publ. employment & $f r a c p u b=\frac{\bar{N}^{g}}{1-U}$ & 0.1872 \\
Vacancy filling rate (private) & $\bar{q}^{p}$ & 0.7000 \\
Vacancy filling rate (public) & $\bar{q}^{g}$ & 0.8000 \\
Gov. SS spending & $\omega^{G}=\bar{G} / \bar{Y}^{\text {tot }}$ & 0.2131 \\
Gov. SS purchases & $\omega^{C g}=\bar{C}^{g} / \bar{Y}^{t o t}$ & 0.0756 \\
Gov. SS investment & $\omega^{I g}=\bar{I}^{g} / \bar{Y}^{t o t}$ & 0.0355 \\
SS debt-to-annual-GDP ratio & $\omega^{b}=\bar{p}_{B}^{1-\omega-\psi} \bar{b} /\left(4 \bar{Y}^{\text {tot }}\right)$ & 0.4831 \\
SS subsidy-to-GDP ratio & $\omega^{s}=\bar{p}_{B}^{1-\omega-\psi} \bar{S}_{\bar{u}} b / \bar{Y}^{t o t}$ & 0.1543 \\
Replacement ratio & $r r s=\frac{\kappa^{B}}{\left(1-\bar{\tau}^{w}\right) \bar{w}}$ & 0.6940 \\
\hline
\end{tabular}

Source: Original data from European Commission, Eurostat and OECD, own calculations for the ratios and implicit tax rates; normalization as described in the main text.

of public to total employment averaged fracpub $=18.72 \%$. For rest of EMU, we find $\bar{U}^{*}=$ $8.44 \%$ and fracpub $^{*}=18.14 \%$.

The OECD calculates replacement ratios for different types of households (see www.oecd.org/els/social/workincentives) depending on their relative income and other characteristics and calculates a "short-run" replacement ratio (average replacement ratio enjoyed in the first 12 months of the unemployment spell). We have that the sample averages for Spain in the period 2001-2008 are 69.4\%. For the rest of EMU, an analogous procedure yields $r r s^{*}=70.5 \%$. Following Christoffel et al. (2009), we set the vacancy-filling probabilities in the private and public sector to $\bar{q}^{p}=\bar{q}^{p, *}=0.7$ and $\bar{q}^{g}=\bar{q}^{g, *}=0.8$, respectively.

We normalize steady-state PPI inflation rates to one, $\bar{\pi}_{A}=\bar{\pi}_{B}=1$, which in turn implies $\bar{\pi}=\bar{\pi}^{*}=1$. Furthermore, we set net foreign asset positions to zero, $\bar{d}=\bar{d}^{*}=0$, implying trade balance between both regions in the steady state. The calibration for the foreign country is performed following a similar strategy and is summarized in Table 2.

\subsubsection{Other parameter values}

We set the Calvo parameter $\theta_{P}$ to 0.75 , which implies that nominal prices are fixed on average for four quarters. This is calibrated somewhere in the middle of the range typically reported in the literature. Coenen et al. (2008) and Smets and Wouters (2003) estimate an average price duration for optimal price setting of ten quarters using full information Bayesian estimation techniques, while Del Negro et al. (2005) only report an average price duration of three quarters. Micro-data for the euro area on price setting reports relatively low price durations with a median of around 3.5 quarters (i.e. close to one year; see Alvarez et al., 2006; for a 
Table 2: Targeted values (rest of EMU)

\begin{tabular}{|c|c|c|}
\hline Target & Symbol & Value \\
\hline (Average) Labor income tax rate & $\bar{\tau}^{w *}$ & 0.2225 \\
\hline Bond tax rate & $\bar{\tau}^{b *}$ & 0.1267 \\
\hline VAT rate & $\bar{\tau}^{\mathcal{c} *}$ & 0.0995 \\
\hline Social security contribution rate & $\bar{\tau}^{S C *}$ & 0.1706 \\
\hline Capital tax rate & $\bar{\tau}^{k *}$ & 0.0704 \\
\hline Unemployment rate & $\bar{U}^{*}$ & 0.0844 \\
\hline Fraction of publ. employment & fracpub ${ }^{*}=\frac{\overline{N^{*}}}{1-\bar{U}^{*}}$ & 0.1814 \\
\hline Vacancy filling rate (private) & $\bar{q}^{p *}$ & 0.7000 \\
\hline Vacancy filling rate (public) & $\bar{q}^{g *}$ & 0.8000 \\
\hline Gov. SS spending & $\omega^{G *}=\bar{G}^{*} / \bar{Y}^{t o t *}$ & 0.2256 \\
\hline Gov. SS purchases & $\omega^{C g *}=\bar{C}^{g *} / \bar{Y}^{t o t *}$ & 0.0985 \\
\hline Gov. SS investment & $\omega^{I g *}=\bar{I}^{g *} / \bar{Y}^{t o t *}$ & 0.0238 \\
\hline SS debt-to-GDP ratio (annualized) & $\omega^{b *}=\left(\bar{p}_{B}^{*}\right)^{-\left(\omega-\psi^{*}\right)} \bar{b}^{*} /\left(4 \bar{Y}^{t o t *}\right)$ & 0.6896 \\
\hline SS subsidy-to-GDP ratio & $\omega^{S *}=\left(\bar{p}_{B}^{*}\right)^{-\left(\omega-\psi^{*}\right)} S \bar{u} b^{*} / \bar{Y}^{t o t *}$ & 0.2126 \\
\hline Replacement ratio & $r r s^{*}=\frac{\kappa^{B *}}{\left(1-\bar{\tau}^{w *}\right) \bar{w}^{*}}$ & 0.7050 \\
\hline
\end{tabular}

Source: Original data from European Commission, Eurostat and OECD, own calculations for the ratios and implicit tax rates; normalization as described in the main text.

summary of more recent micro-evidence). The steady-state mark-up of intermediate goods producers over marginal cost is set at 20 percent, implying that $\epsilon=6$ as in Blanchard and Galí (2010). Regarding nominal wage stickiness, Christoffel et al. (2009), Colciago et al. (2008) and de Walque et al. (2009) find a rather high degree of stickiness for wages on existing jobs. We opt for a middle value of these studies and set $\theta_{w}=0.8$. According to de Walque et al. (2009), newly created jobs face a somewhat higher wage flexibility, but are still tied to existing (previous period's) wages. Hence, we choose $\theta_{w}^{n}=0.7 .{ }^{12}$

Regarding preference parameters, we choose standard values: $\beta=0.99, \sigma_{c}=2$ and $h=0.85$ (see, for example, Smets and Wouters, 2003; or Coenen et al., 2008). The home bias parameter in each country is set such that the share of domestically-produced goods in total private consumption expenditure equals its empirical counterpart, 66\% in Spain and $93 \%$ in the rest of EMU, yielding $\psi=0.56$ and $\psi^{*}=0.03$. For the fraction of liquidity constraint consumers, we choose $\mu=0.4$ following Forni et al. (2009). ${ }^{13}$

According to Schmitt-Grohé and Uribe (2003), it is sufficient to chose a rather small value for the risk premium parameter on international bonds in order to generate a stable equilibrium. So we opt for $\psi_{d}=\psi_{d}^{*}=0.01$. For the monetary policy rule, we chose coefficients associated with a classical Taylor rule (see Taylor, 1993; as well as Woodford, 2001, for a discussion).

On the production side, we set $\alpha=0.4$; the resulting steady-state labor share,

\footnotetext{
${ }^{12}$ De Walue et al. (2009) find this by matching their model to fit US data. To us, it seems reasonable that the tie of new jobs' wages to existing wages may be even higher in Europe due to a higher degree of collective wage bargaining.

${ }^{13}$ We have performed sensitivity analysis with respect to this parameter and find that the main results remain robust. These results are available upon request.
} 
$\left(1+\bar{\tau}^{s c}\right)\left(\bar{w}^{p} \bar{N}^{P}+\bar{w}^{g} \bar{N}^{g}\right) \bar{p}_{B}^{1-\omega-\psi} / Y^{\text {tot }}=52.9 \%$, is very close to the average labor share in Spain over the period 1999-2008 (53.8\%). Capital, both public and private, depreciates at rate $\delta^{g}=\delta^{p}=0.025$. These are standard values in the literature; see, for example, Cooley and Prescott (1995) or Burda and Weder (2002). We set the elasticity of production with respect to public capital to $\eta=0.015$, which is within the range of estimates in the literature (see Aschauer, 1989, Nadiri and Mamuneas, 1994, Holtz-Eakin, 1994, Kamps, 2004, and the discussion in Leeper et al., 2010). The investment adjustment cost parameter is chosen to be $\kappa_{I}=2.48$, in line with Schmitt-Grohé and Uribe (2006). On the labor market, following Petrongolo and Pissarides (2001), we set the matching elasticity in the private sector to the standard value of $\varphi^{p}=0.5$. We, further, follow Afonso and Gomes (2008) in setting $\varphi^{g}=0.3<\varphi^{p}$ which implies that vacancies are relatively more important for the matching process in the public sector than unemployment. For the separation rates, we chose $s^{p}=0.06$ in line with Christoffel et al. (2009) which is also close to the values in Boscá et al. (2009a, 2009b, 2010). Again, we follow Afonso and Gomes (2008) and Gomes (2009) who find that $s^{g}=1 / 2 \cdot s^{p}$. We set the bargaining power equal to private sector matching elasticity, $\xi=\varphi^{p}=0.5$ to comply with the condition of Hosios (1990), which is a standard proceeding in the literature. Following Silva and Toledo (2009), we target training costs to be equal to $55 \%$ of a new hire's quarterly wage, i.e. $\kappa_{t c}=0.55 \cdot \bar{w}^{p}$.

The remaining parameters are calculated in order to replicate the steady-state ratios mentioned above. This yields corresponding values for private-sector and public-sector matching efficiency $\kappa_{e}^{p}$ and $\kappa_{e}^{g}$, private-sector vacancy posting costs $\kappa_{v}^{p}$ and unemployment benefits $\kappa^{B}$, as well as the corresponding foreign country counterparts. 
Table 3: Baseline parameter calibration

\begin{tabular}{lcc}
\hline Parameter & Symbol & Value \\
\hline Relative size of home country & $\omega$ & 0.1 \\
& & \\
Monetary policy & & \\
\hline Interest rate smoothing & $\rho_{R}$ & 0.9 \\
Stance on inflation & $\phi_{\pi}$ & 1.5 \\
Stance on output gap & $\phi_{y}$ & 0.5 \\
& & \\
Fiscal policy & & \\
\hline Lump-sum tax smoothing & $\rho_{T}=\rho_{T}^{*}$ & 0 \\
Capital tax smoothing & $\rho_{\tau^{k}}$ & 0 \\
SSC smoothing & $\rho_{\tau^{s c}}$ & 0 \\
VAT smoothing & $\rho_{\tau^{c}}$ & 0 \\
Bond tax smoothing & $\rho_{\tau^{b}}$ & 0 \\
Labor income tax smoothing & $\rho_{\tau^{w}}$ & 0.1 \\
Persistence pub. investment & $\rho_{I^{g}}$ & 0 \\
Persistence government purchases & $\rho_{C^{8}}$ & 0 \\
Persistence public employment & $\rho_{n g}$ & 0.85 \\
Persistence public wages & $\rho_{w_{g}}$ & 0 \\
Stance on debt (lump-sum tax) & $\phi_{T}=\phi_{T}^{*}$ & 0 \\
Stance on debt (cap. tax) & $\phi_{\tau^{k}}$ & 0 \\
Stance on debt (SSC) & $\phi_{\tau^{s c}}=\phi_{\tau^{s c}}^{*}$ & 0 \\
Stance on debt (VAT) & $\phi_{\tau^{c}}$ & 0 \\
Stance on debt (bond tax) & $\phi_{\tau^{b}}$ & 0 \\
Stance on debt (lab. tax) & $\phi_{\tau^{w}}$ & 0.1 \\
Stance on debt (gov. purchases) & $\phi_{C^{g}}$ & 0 \\
& & \\
\hline
\end{tabular}


Table 3 (cont.): Baseline parameter calibration

\begin{tabular}{|c|c|c|}
\hline Parameter & Symbol & Value \\
\hline \multicolumn{3}{|l|}{ Price and wage stickiness } \\
\hline$\overline{\text { Calvo parameter (prices) }}$ & $\theta_{P}$ & 0.75 \\
\hline Market power (markup) & $\epsilon$ & 6 \\
\hline Calvo parameter (existing wages) & $\theta_{w}$ & 0.8 \\
\hline Calvo parameter (new wages) & $\theta_{w}^{n}$ & 0.7 \\
\hline \multicolumn{3}{|l|}{ Preferences } \\
\hline Share of RoT consumers & $\mu$ & 0.4 \\
\hline Discount rate & $\beta$ & 0.99 \\
\hline Risk aversion & $\sigma_{\mathcal{C}}$ & 2 \\
\hline Habits in consumption & h & 0.85 \\
\hline Home bias & $\psi ; \psi^{*}$ & $0.56 ; 0.03$ \\
\hline \multicolumn{3}{|l|}{ Trade in internat. bonds } \\
\hline$\overline{\text { Risk premium parameter }}$ & $\psi_{2}=\psi_{2}^{*}$ & 0.01 \\
\hline \multicolumn{3}{|l|}{ Production } \\
\hline$\overline{\text { Private sector capital depreciation }}$ & $\delta^{k}$ & 0.025 \\
\hline Public sector capital depreciation & $\delta^{g}$ & 0.025 \\
\hline Private sector capital share in prod. & $\alpha$ & 0.4 \\
\hline Public sector capital influence in prod. & $\eta$ & 0.015 \\
\hline Adjustment cost parameter & $\kappa_{I}$ & 2.48 \\
\hline TFP scaling parameter & $\epsilon^{a} ; \epsilon^{a *}$ & $0.42 ; 0.45$ \\
\hline \multicolumn{3}{|l|}{ Labor market } \\
\hline Matching elasticity (private sector) & $\varphi^{p}$ & 0.5 \\
\hline Matching elasticity (public sector) & $\varphi^{g}$ & 0.3 \\
\hline Separation rate (public sector) & $s^{g}$ & 0.03 \\
\hline Separation rate (private sector) & $s^{p}$ & 0.06 \\
\hline Bargaining power & $\xi$ & 0.5 \\
\hline Private sector matching efficiency & $\kappa_{e}^{p} ; \kappa_{e}^{p *}$ & $0.44 ; 0.48$ \\
\hline Public sector sector matching efficiency & $\kappa_{e}^{g} ; \kappa_{e}^{g *}$ & $0.30 ; 0.32$ \\
\hline Vacancy posting costs & $\kappa_{v} ; \kappa_{v}^{*}$ & $0.15 ; 0.03$ \\
\hline Training costs & $\kappa_{t c}, \kappa_{t c}^{*}$ & $0.35 ; 0.26$ \\
\hline Unemployment benefits & $\kappa_{B} ; \kappa_{B}^{*}$ & $0.37 ; 0.26$ \\
\hline
\end{tabular}

Notes: Parameter values chosen as described in the main text. Fiscal instrument used is labor income tax (hence, fiscal policy's stance on debt deviations, $\phi_{X}$, are set to zero for all other fiscal instruments) and home and foreign country parameters are equal (both true unless indicated differently). For the 'fiscal devaluation' simulation to follow, the persistence and stance parameters $\rho_{T}^{*}, \rho_{\tau^{s c}}$, and $\phi_{T}^{*}$ and $\phi_{\tau^{s c}}$ are changed according to the description in the main text and $\phi_{\tau^{w}}=\phi_{\tau^{w}}^{*}=0$ (indicated by ${ }^{\dagger}$ in the table). 


\section{Main analysis}

In this section, we describe the main analysis conducted in this paper. In order to do so, we first describe the simulation design and, then, discuss the short and long-run results, respectively.

\subsection{Simulation design}

The main focus of our paper is to analyze short and long-run effects of permanent changes in a number of fiscal instruments that are aimed at achieving fiscal consolidation. Along the lines of recent actions taken or announced by the Spanish government, the instruments we consider are public wages, public employment, government purchases and public investment on the expenditure side, as well as VAT and labor income tax rates on the revenue side. In order to make them comparable, we calibrate the change in each fiscal instrument such that the primary deficit-to-GDP ratio falls by one percentage point ex ante, that is, holding constant everything other than the instrument being changed. For simplicity, we assume that at the time of the fiscal change the economy is in steady state. Therefore, when calculating ex-ante effects, all variables are set equal to their baseline steady state values. The primary deficit to GDP ratio is given by

$$
P D_{t}^{\text {ratio }}=\frac{P D_{t}}{Y_{t}^{\text {tot }}} \cdot p_{B t}^{1-\omega-\psi},
$$

where primary deficit $P D_{t}$ is defined in equation (36). Notice that, since $P D_{t}$ and $Y_{t}^{t o t}$ are expressed in terms of CPI and PPI, respectively, we adjust the ratio of both variables by the CPI-to-PPI ratio, $P_{t} / P_{A t}=p_{B t}^{1-\omega-\psi}$. From equation (46), the change in primary deficit required to bring about a one percentage point reduction in the deficit ratio ex-ante is given by

$$
d(P D)=-0.01 \cdot \bar{Y}^{\text {tot }}\left(1 / \bar{p}_{B}\right)^{1-\omega-\psi},
$$

where bars denote baseline steady state values. From the definition of real primary deficit, equation (36), we can then calculate the necessary change in the corresponding fiscal instrument. In the case of a change in consumption taxes, ceteris paribus the change in primary deficit equals $d(P D)=-d\left(\tau^{c}\right) \bar{C}$. Combining this with (47), we then have

$$
d\left(\tau^{c}\right)=0.01 \cdot\left(\frac{\bar{p}_{B}^{1-\omega-\psi} \bar{C}}{\bar{Y}^{t o t}}\right)^{-1}
$$

where $\left(\bar{p}_{B}^{1-\omega-\psi} \bar{C}\right) / \bar{Y}^{t o t}$ is the share of private consumption in GDP. In the case of a change in wage income taxes, similar calculations yield

$$
d\left(\tau^{w}\right)=0.01 \cdot\left(\frac{\bar{p}_{B}^{1-\omega-\psi} \bar{N}^{t o t} \bar{w}}{\bar{Y}^{t o t}}\right)^{-1}
$$

where $\bar{w} \equiv\left(\bar{N}^{p} / \bar{N}^{t o t}\right) \bar{w}^{p}+\left(\bar{N}^{g} / \bar{N}^{t o t}\right) \bar{w}^{g}$ is the economy-wide average real wage. For PPIdeflated expenditure instruments, the required percentage change is given by $d(X) / \bar{X}=$ $-0.01\left(\bar{X} / \bar{Y}^{t o t}\right)^{-1}$, for $X=C^{g}, I^{g}$. Finally, the required percentage changes in public wages 
or public employment are given by

$$
\frac{d(X)}{\bar{X}}=-0.01\left(\frac{\bar{p}_{B}^{1-\omega-\psi}\left(1-\bar{\tau}^{w}\right) \bar{w}^{g} \bar{N}^{g}}{\bar{Y}^{t o t}}\right)^{-1},
$$

for $X=w^{g}, N^{g}$, where we have taken into account the fact that changes in either instrument have a direct effect both on public consumption and on tax receipts (see equations 36 and 37).

Each fiscal measure is implemented by changing the corresponding long-run target, $\bar{X}$, such that the measure is permanent. For instance, in the case of the consumption tax rate, the new long-run target is given by $\left(\bar{\tau}^{c}\right)^{\prime}=\bar{\tau}^{c}+0.01\left(\bar{p}_{B}^{1-\omega-\psi} \bar{C} / \bar{Y}^{\text {tot }}\right)^{-1}$; for public purchases, it is given by $\bar{C}^{\prime}=\bar{C}\left[1-0.01\left(\bar{X} / \bar{Y}^{t o t}\right)^{-1}\right]$. Furthermore, we assume that the actual instrument $X_{t}$ reacts immediately, by setting the smoothing coefficients in the fiscal rules to zero except for the labor income tax rate as we set $\rho_{\tau^{w}}>0$ and for the drop in public employment, which is implemented gradually by assuming a positive autocorrelation coefficient in the public employment rule (see Table 3). Given that, because of labor market regulations, public employment cannot be reduced immediately in praxis either, we believe this to be a realistic feature of our model.

As discussed in the description of the fiscal block, in order to guarantee stability of public debt at least one fiscal instrument must eventually react to deviations of the public debt ratio from a long-run target; that is, in the set of fiscal rules described by (39) and (40), for at least one instrument $X$ we must have $\phi_{X} \neq 0$. We assume the tax rate on labor income to be that instrument (i.e. we set $\phi_{\tau^{w}}>0$ ). Furthermore, we assume that labor income taxes react to the change in the debt ratio with a 4-year delay (i.e., in equation (39), we set $e_{\tau^{w}}^{a u x}=0$ for $t=1, \ldots, 16$ and $e_{\tau^{w}}^{a u x}=1$ thereafter), so as to isolate the short-run response of public deficit and debt from the fiscal rule.

\subsection{Expenditure components}

We start our analysis by having a look at the effects of a permanent reduction in government purchases, $\bar{C}^{g}$. While our model is able to differentiate between different public consumption components, this corresponds to how reductions in government consumption are traditionally analyzed in conventional models. For all simulations to follow in this section, we plot the dynamics for the first 5 years, i.e. 4 years in which the fiscal rule has been shut off plus the first year in which it is activated again.

We see in Figure 1 that lower government purchases reduce private output and, thus, GDP. Remember that the entire cut in public purchases takes place immediately so there is no gradual change. Hence, there is an immediate and rather large drop in private production and GDP due to lower public demand. Optimizing households increase consumption because of the positive wealth effect induced by expected future tax decreases associated to the lower level of government spending today (and, thus, lower levels of debt tomorrow). The increase in private demand alleviates the drop in public demand such that private production as well as GDP start to increase when Ricardian households start to consume more. The fall in aggregate demand makes firms, first, decrease prices generating deflationary pressure and, second, decrease production implying less labor and capital demand. Thus, private employment falls and unemployment rises. As in Galí et al. (2007), liquidity-constrained 
households decrease consumption because they are not subject to the positive wealth effect but only suffer the income loss due to the fall in employment. The average private-sector real wage increases on impact, because the fall in consumer prices dominates the fall in nominal wages, but this is not sufficient to compensate for the reduced employment level among rule-of-thumb households. As consumer price inflation returns to baseline, real wages start falling due to the persistent decrease in workers' re-employment probability and hence in their reservation wage (i.e. the their fall-back utility). Because optimizing households make up the majority of total population, aggregate private consumption increases through the wealth effect. Private-sector unit labor costs, $\left(1+\tau_{t}^{s c}\right) w_{t}^{p} N_{t}^{p} / Y_{t}$, decrease on impact, because the drop in private employment is large enough to dominate the initial real wage increase and the fall in private output. Lower production also implies a fall in capital demand and, thus, private investment. The drop in unit labor costs and hence in producer prices leads to an increase in the terms of trade, i.e. home goods become relatively cheaper, which in turn yields an increase in real net exports. The fiscal balances improve as can be noticed by the decrease in both the primary deficit-to-GDP and the debt-to-GDP ratios. The initial (though small) increase in the debt-to-GDP ratio is due to the fact that the denominator of the ratio sharply decreases on impact, while the nominator gradually adapts. In the discussion on fiscal multipliers, the effects just described are, generally, understood to typically accompany public spending multipliers (see, among others, Cogan et al. 2009; Coenen et al., 2010a; and Hebous, 2010). We will see below and in Table 5, however, that, when talking about the size of (not only long-run) fiscal spending multipliers, it matters which spending component we actually consider. From period 17 onward, the labor income tax rule comes into play. We see that this fosters private production and private demand. As the effects are opposite to a labor income tax increase, which is described later on, we refer to the corresponding simulation in the following subsection for more details.

Figure 2 summarizes the dynamic effects of a gradual cut in public employment for selected variables. We note that, while the effects on private consumption and fiscal balances tend to be quite similar, there are notable differences in the dynamics of private production, GDP, employment and private investment. Furthermore, all the effects differ in size. This is because the two measures - even though both decreasing public consumption - produce different adjustment paths. Reducing the level of public employment implies an increase in unemployment and, thus, a decrease in the probability for unemployed workers finding a job in both the public and also the private sector. This yields a reduction in average private sector wages and, thus, unit labor costs immediately. Lower unit labor costs allow firms to cut prices, now more persistently, which improves the terms of trade, fosters demand for Spanish goods in the rest of EMU and, thus, increases exports. In contrast to a cut in government purchases, higher (internal but also export-driven) private demand, now without a loss of public demand, makes private firms increase production. They do so by increasing private employment and, eventually, higher private capital input. The unemployment rate still increases as the additional private employment cannot compensate for the loss in public employment. The initial fall in investment can be explained by the rise of the real interest rate, which in turn is due to the fall in home CPI inflation together with the limited influence of Spanish aggregates on area-wide nominal interest rate policy. Higher private employment and production, however, augment marginal productivity of capital and, eventually, compensates for this effect generating an increase in private investment. Because of lower private wages, less public employment and an increase in unemployment, consumption of RoT households falls, while it increases for optimizing households due to 
Figure 1: Permanent reduction in home government purchases
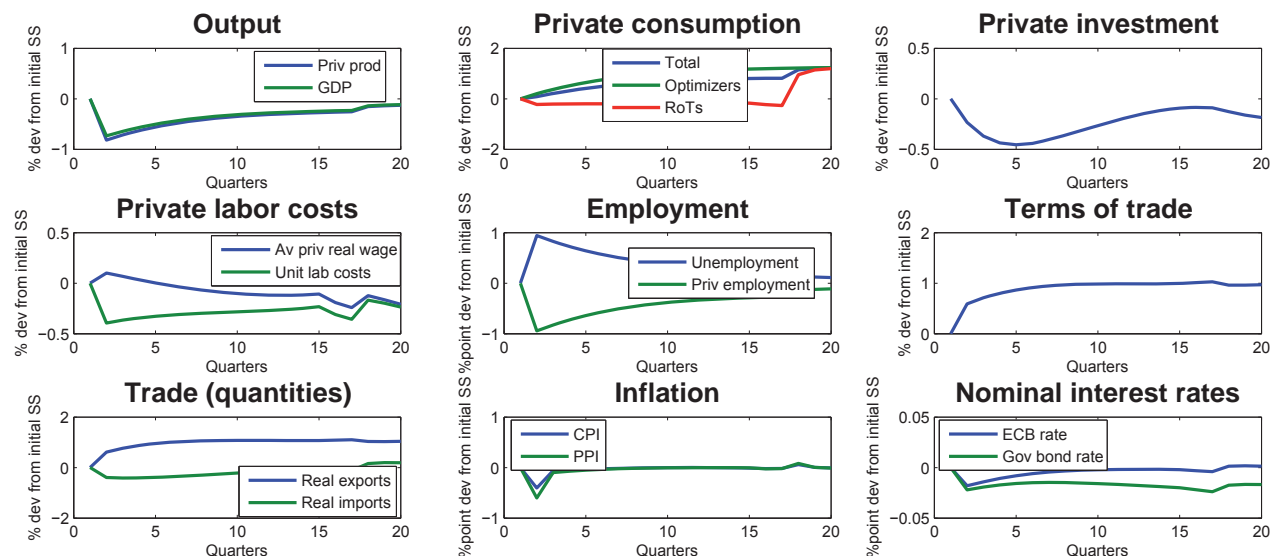

$\frac{\infty}{\frac{\omega}{\sigma}}$ Primary deficit (to GDP ratio)
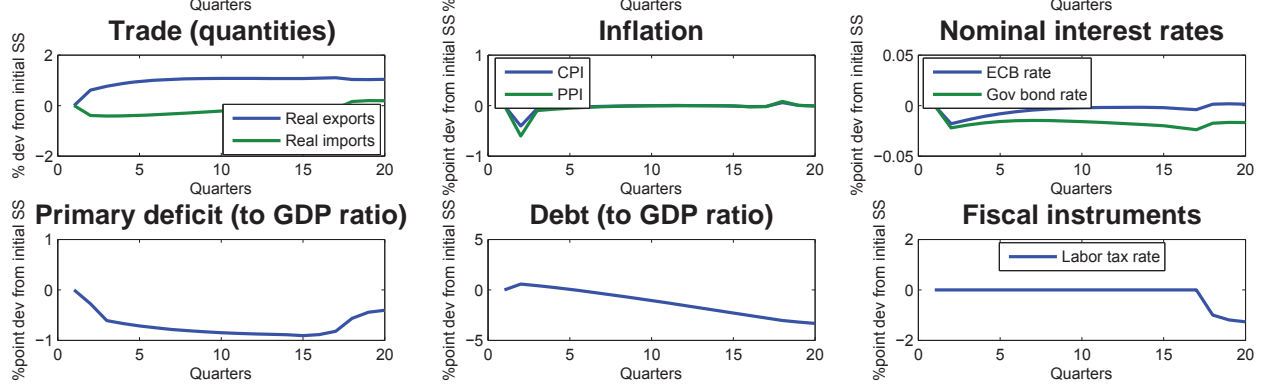

Notes: Transition dynamics of selected home country variables following a permanent reduction in government purchases. The figure shows percentage deviations from initial steady state (percentage point deviations for tax rates, interest rates, (un)employment rates, inflation and X-to-GDP ratios).

anticipation of lower future taxation; the latter effect dominates, and thus total private consumption rises. Overall, the effects of a reduction in public employment are similar to those of a reduction in public purchases. The most significant difference between both measures is the fact that, when reducing public employment, private production increases while it decreases when cutting government purchases. Another noteworthy issue is the fact that GDP falls when shedding public employment. The effect on private production is mainly due to the wage reduction just described. The effect on GDP is due to the definition of real GDP itself, namely the sum of private production and government production (measured as the public sector wage bill). The latter falls when dismissing public sector workers. Because private production increases along the transition path, so does GDP eventually (see also Table 5). We should bear in mind, however, that this is basically a matter of definition because public sector production is measured by its inputs (according to national accounting). Perhaps more important is the positive spillover effects that this measure has on private sector output and employment, which differ from the effects of a cut in public purchases. However, we should also note that, in our model, we neglect any potentially positive (say, for instance, private productivity-enhancing) spillover from public employment to the private sector. Government services only enter households' utility. As it is not clear how much public employment (positively) affects private sector production, we chose to abstract from this issue. Nevertheless, the positive effects of public sector employment cuts found here are certainly diminished in practice (or may even vanish when public employment reduction is misplaced). 
Figure 2: Permanent reduction in home government employment
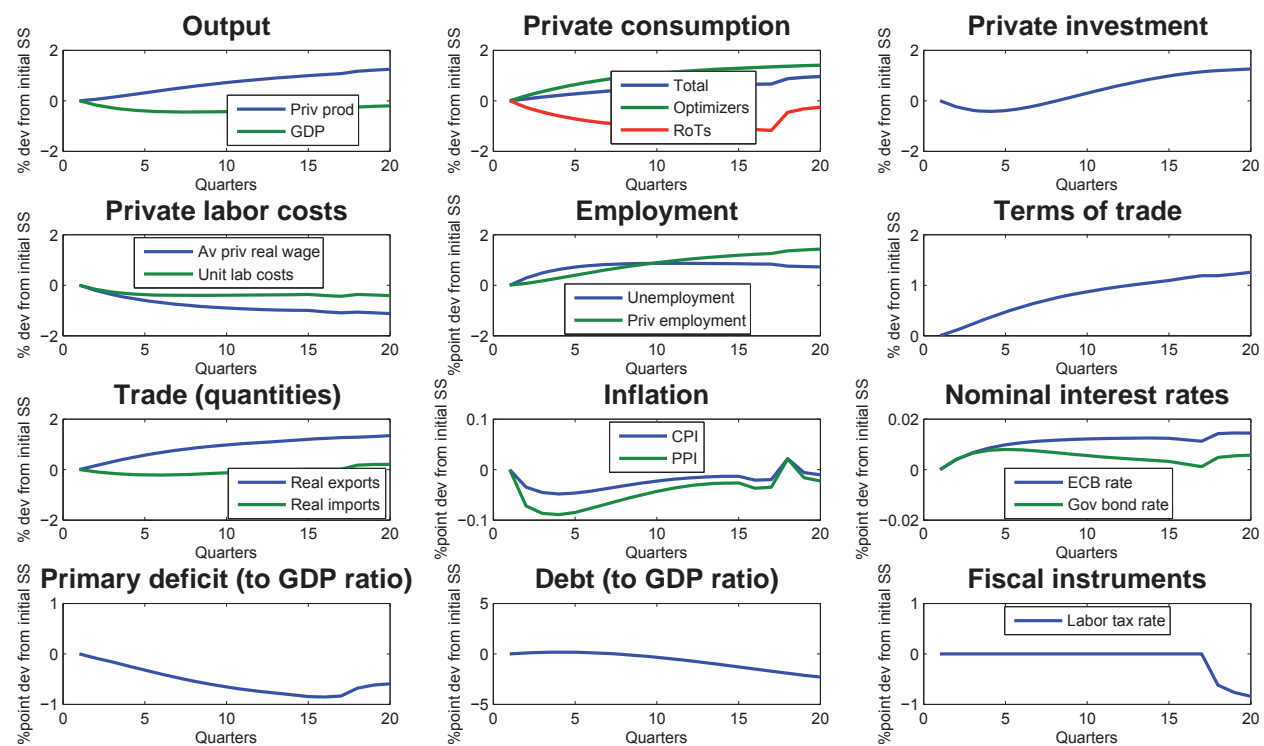

Notes: Transition dynamics of selected home country variables following a permanent reduction in public employment. The figure shows percentage deviations from initial steady state (percentage point deviations for tax rates, interest rates, (un)employment rates, inflation and X-to-GDP ratios).

Besides reducing the public sector wage bill by dismissing public employees, the government can also decide to cut public wages. The effects of this measure are shown in Figure 3. Cutting public sector wage payments reduces private sector wage claims and, thus, unit labor costs. Under this measure, the workers' fall-back utility is not influenced by a lower probability of finding a job in the public sector, but by the fact that, when having found a job in the public sector, the corresponding gain is less. Again, lower labor costs allows firms to cut prices, which improves the terms of trade and fosters exports to the rest of EMU. The higher demand for Spanish goods is produced with more employment and more capital inputs, the latter increasing investment eventually. Furthermore, as there are no workers laid off in this scenario, the increase in private employment now significantly reduces unemployment. Regarding the consumption reaction of liquidity-constrained consumers, the reduction in unemployment is not sufficient to compensate for the reduction in public and private sector wages, while, again, consumption for optimizing households increases yielding a rise in aggregate consumption. Therefore, we find a cut in public sector wages to be beneficial for private sector output and for both private sector and total employment. Now, GDP increases because the GDP-deflator takes care of the public sector wage reduction. Our simulations suggest that cutting public sector wages is, in the short and long-run, the most efficient consolidation strategy in terms of economic activity, i.e. production and employment (see also Table 5). However, again, we must point to some caveats regarding this finding. Cutting public sector wages (too much) may imply that the public sector no longer finds (qualified enough) workers to do the relevant tasks, or that public sector workers would no longer provide the necessary effort (a possibility the literature on efficiency wages points to). 
In both cases, the provision of public services may be affected. Given that public services enter the households' utility, such measures may not necessarily be welfare-enhancing even though they increase economic activity. Furthermore, our model neglects the possibility that government services indirectly foster private-sector productivity.

Figure 3: Permanent reduction in home government wages
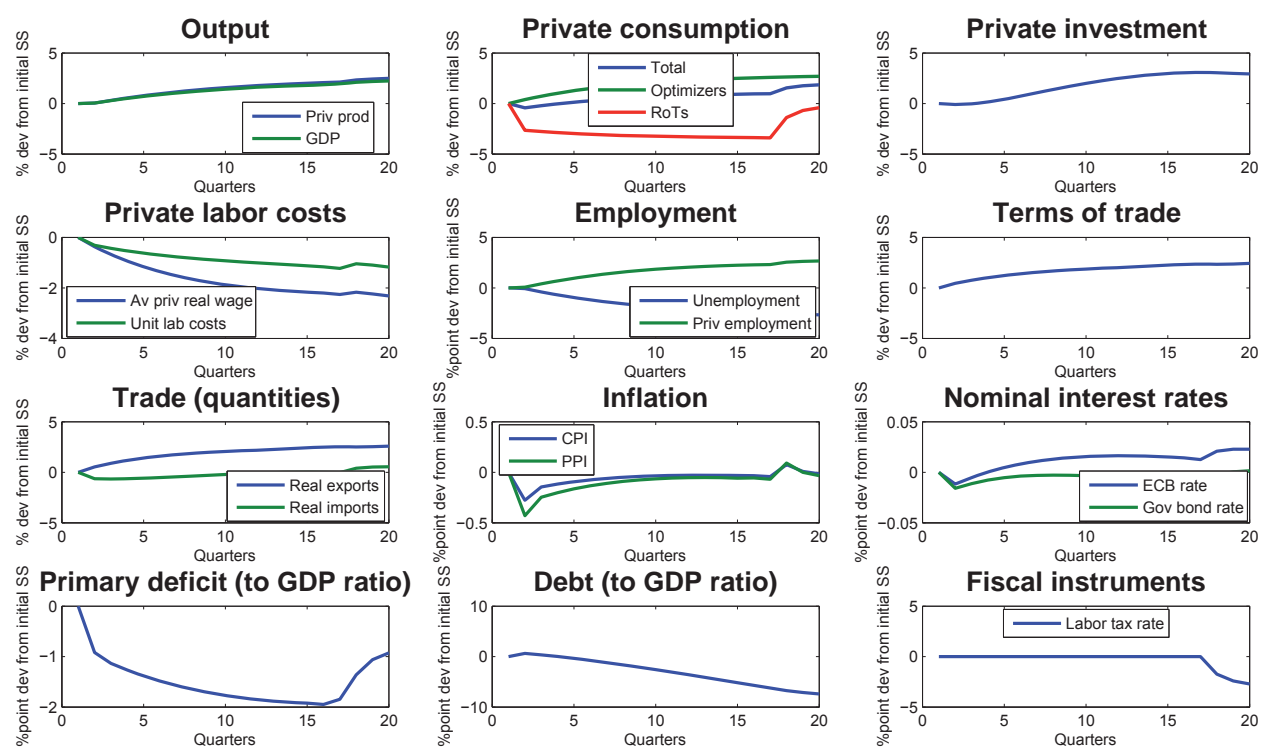

Notes: Transition dynamics of selected home country variables following a permanent reduction in public wages. The figure shows percentage deviations from initial steady state (percentage point deviations for tax rates, interest rates, (un)employment rates, inflation and X-to-GDP ratios).

Another deficit-reducing measure recently approved in Spain is an important cut in public investment. The model-simulated effects from such a measure can be seen in Figure 4. A decrease in public investment impacts the economy through two different angles. While the reduction for public investment demand as such affects the economy in an analogous way to the reduction in public purchases discussed before, the cut in public investment additionally affects private sector productivity through a gradual decline in the public capital stock. In this respect, the cut in public investment acts analogously to a permanent (but lagged) negative productivity shock. Overall, the short run effects on output, employment, international competitiveness, etc., are quantitatively similar to those of a cut in public purchases (see Figure 1), although the contractionary effects are slightly larger due to the additional productivity channel. As can be seen in Table 4, the difference in contractionary effects between both measures widens as time goes by and the gradual deterioration in private-sector productivity starts dominating. Our subsequent analysis of steady-state results in section 3.5 will show that public investment cuts have far more damaging longrun effects than comparable cuts in public purchases, despite our choice of a relatively small public capital elasticity (the parameter $\eta$ in equation (17)).

Drawing some preliminary conclusions from the above analysis, we see that, when considering government expenditures to be the instrument used for fiscal consolidation, it 
Figure 4: Permanent reduction in home government investment
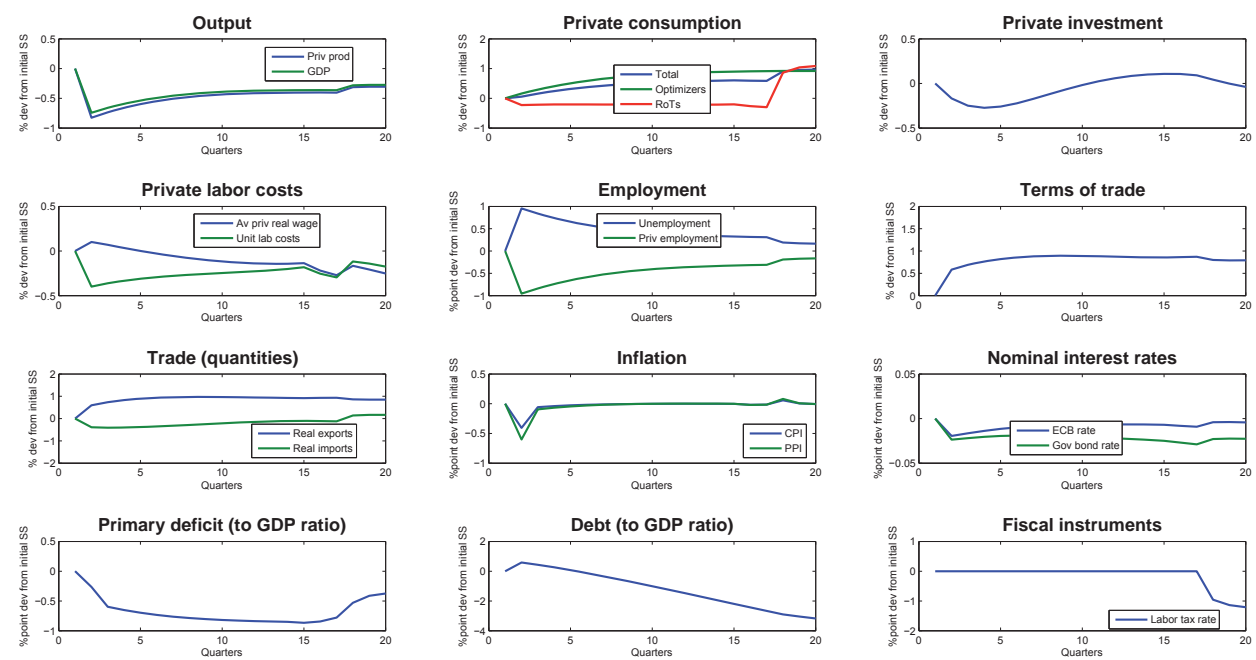

Notes: Transition dynamics of selected home country variables following a permanent reduction in government investment. The figure shows percentage deviations from initial steady state (percentage point deviations for tax rates, interest rates, (un)employment rates, inflation and X-to-GDP ratios).

matters which spending component is cut. A reduction in productivity-enhancing government spending (i.e. public investment) seems to be the more harmful option in terms of economic activity, due to its direct effect on aggregate demand and its negative effects on private-sector productivity (the latter especially in the long-run). Decreasing public consumption seems to be less harmful in terms of production and employment. This is especially so for reductions in public sector wages or public sector employment: first, they do not directly affect demand for private-sector goods; and second, the resulting fall of workers' outside option allows firms to reduce unit labor costs and thus improve their international competitiveness.

\subsection{Revenue components}

In this section, we analyze the effects of an increase in labor income taxation and the VAT rate. Figure 5 shows the effects of a permanent increase in the labor income tax rate. An increase in the labor income tax rate implies a decrease in the take-home pay which yields a large fall in the consumption of RoT households. Optimizing households, even though increasing consumption because of the positive long-run wealth effect, cannot compensate for this drop. Less demand yields a drop in private production and GDP, which implies a fall in employment (hence, an increase in unemployment). There are two effects on private-sector real wages. First, the increase in unemployment implies a lower job-finding probability and thus reduced wage claims by workers; second, workers claim higher gross wages because the increase in taxation reduces their take-home pay. Overall, both effects tend to offset each other, implying negligible effects on real wages and unit labor costs. While exports are barely affected, imports fall due to the drop in domestic consumption demand, which 
is partly satisfied by foreign products. Investment increases gradually due to the fall in the ex-ante real interest rates (notice that expected price inflation actually rises as of the impact period, whereas nominal interest rates are barely affected). When the labor income tax rules takes effect after 4 years, we basically observe opposite reactions. However, as the tax rule entails some smoothing, these effects take a while to be completed (see Table 5 for the longrun results).

Figure 5: Labor income taxes
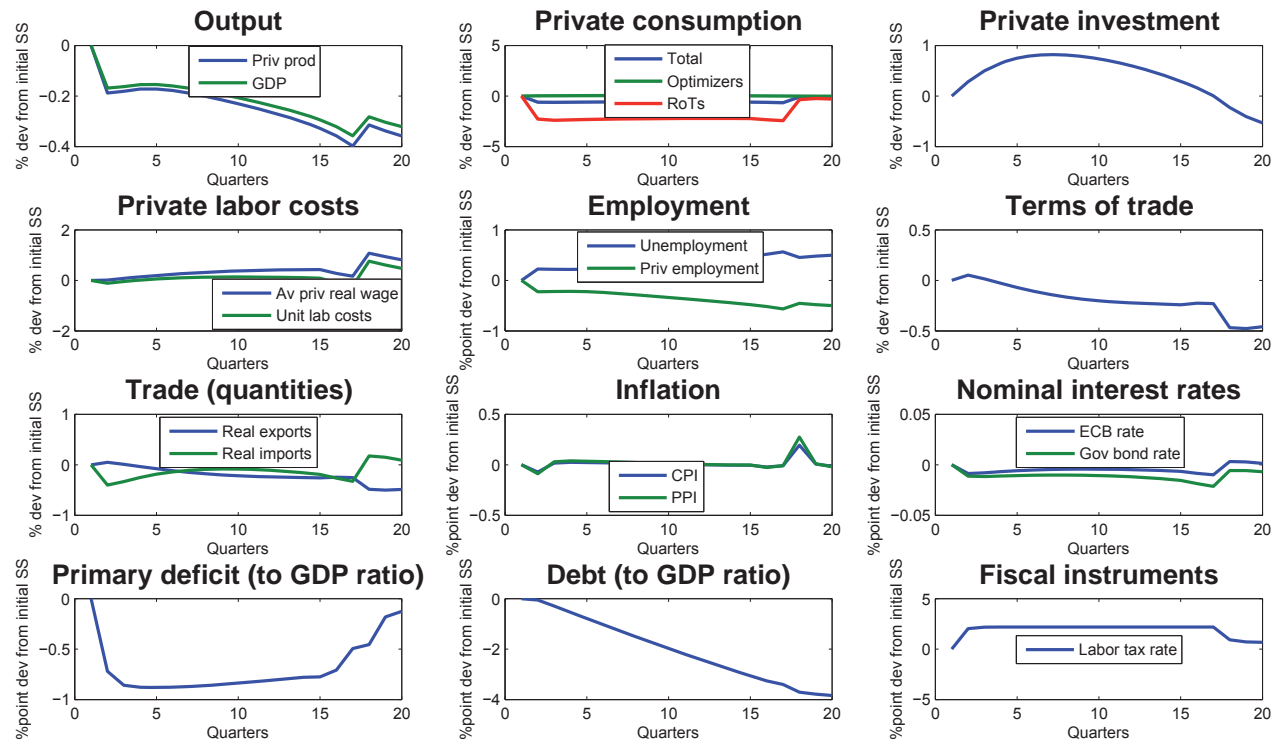

Notes: Transition dynamics of selected home country variables following a permanent increase in the labor income tax rate. The figure shows percentage deviations from initial steady state (percentage point deviations for tax rates, interest rates, (un)employment rates, inflation and X-to-GDP ratios).

The effects of a permanent increase in the VAT rate are pictured in Figure 6. Augmenting VAT sets in train some of the mechanisms described above. As goods and services become more expensive, liquidity-constrained consumers will reduce consumption, while optimizing households slightly increase it due to the wealth effect. As Ricardian households cannot compensate for the drop of RoT consumption, this implies a reduction in private consumption demand and a drop in output, yielding lower labor demand and an increase in unemployment. Private-sector real wages drop slightly, due to the increase in unemployment and the resulting fall in the job-finding probability. In addition, average worker productivity rises because the fall in private employment is larger than the fall in privatesector production. Both effects produce a reduction in unit labor costs and thus in home PPI inflation, with the resulting improvements in the terms of trade and real net exports. Private investment increases gradually for the same reasons as in the case of the hike in labor income taxation. Finally, after-VAT CPI inflation experiences a large increase, whereas before-VAT CPI inflation (not shown in the figure) decreases slightly. Overall, the effects of the increase in indirect taxation are similar although slightly smaller than those following a rise in labor income taxation (see also Table 4). 
Figure 6: Value added taxes
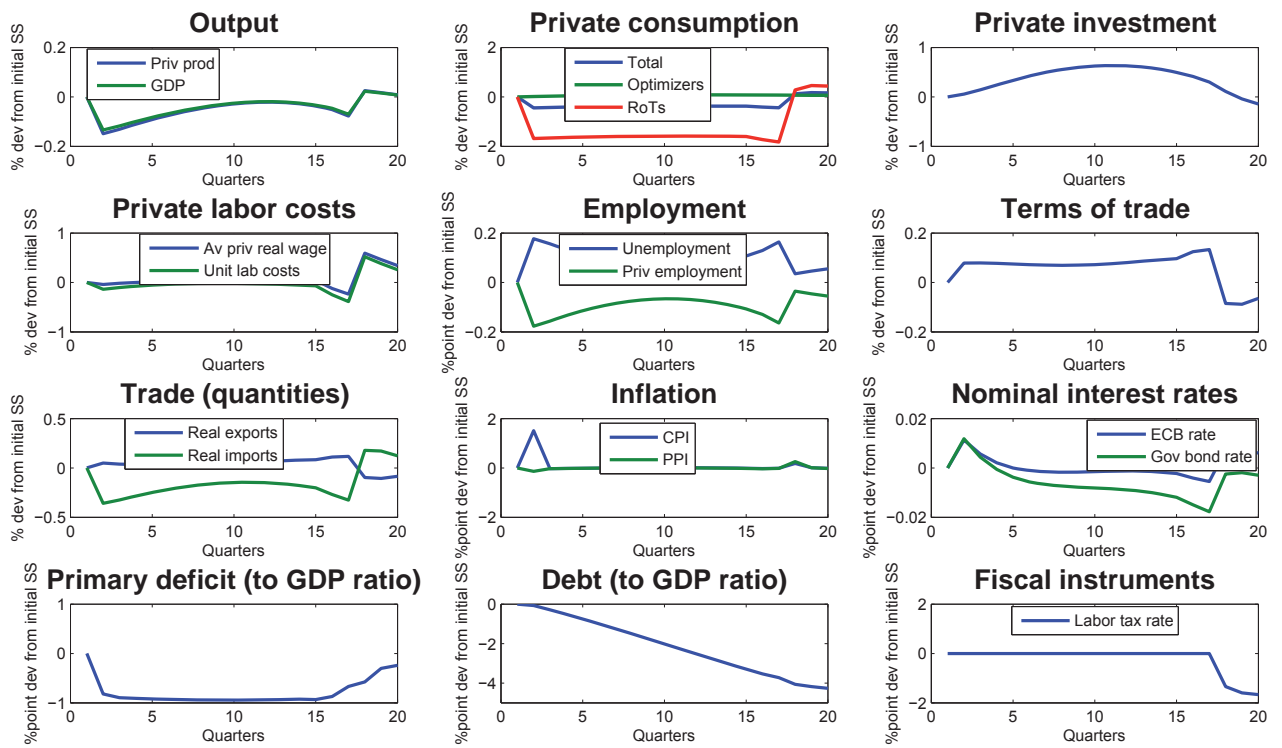

Notes: Transition dynamics of selected home country variables following a permanent increase in the VA tax rate. The figure shows percentage deviations from initial steady state (percentage point deviations for tax rates, interest rates, (un)employment rates, inflation and X-to-GDP ratios). Note that CPI inflation is after-VAT. 


\subsection{Magnitude of short-run impact}

In table 4 , we present a summary of the ex-ante short-run multipliers of each consolidation measure described above. As the table makes clear, a cut in public investment is the most damaging way of performing fiscal consolidation, as it implies the largest losses in real GDP and the largest increases in the unemployment rate. A cut in public purchases follows closely, especially in the very-short run, when the direct effect of both measures on aggregate demand remains the dominant force. As time goes by, however, the negative effect of the gradual decline in public capital on private-sector productivity starts widening the difference in contractionary effects. On the opposite extreme, cuts in public sector wages or employment actually have positive spillover effects on private-sector output and employment. The reasons is twofold. First, the government wage bill is not a component of aggregate demand for domestic privately-produced goods and services and hence does not directly affect it. Second, both measures worsen the outside option of private-sector workers in wage negotiations, which allows firms to lower their labor costs and thus improve their international competitiveness. Both measures differ in their effects on total employment: whereas cutting government wages raises both private-sector and total employment, the reduction in public employment dominates its positive spillover effect on private-sector employment, implying an increase in unemployment. Notice also that, unlike the public wage cuts (which mainly affect the GDP deflator), the fall in public employment implies a reduction in real government output and hence in real GDP. Finally, the two revenue measures (an increase in labor income taxes and consumption taxes) fall somewhere in between, as they imply relatively modest contractionary effects. As discussed before, the bargaining process in the present framework may act towards dampening the effect of distortionary taxation on private-sector wage claims and thus on production and employment. 
Table 4: Short-run multipliers

\begin{tabular}{|c|c|c|c|c|}
\hline Effects of (instrument) on & Year 1 & Year 2 & Year 3 & Year 4 \\
\hline \multicolumn{5}{|l|}{ Public purchases } \\
\hline Real GDP & -0.61 & -0.39 & -0.29 & -0.24 \\
\hline CPI inflation & -0.53 & -0.05 & -0.01 & -0.04 \\
\hline Real private consumption & 0.26 & 0.58 & 0.74 & 0.81 \\
\hline Unemployment & 0.78 & 0.49 & 0.35 & 0.28 \\
\hline Terms of Trade & 0.74 & 0.95 & 0.99 & 1.01 \\
\hline \multicolumn{5}{|l|}{ Public employment } \\
\hline Real GDP & -0.30 & -0.44 & -0.41 & -0.34 \\
\hline Real priv. production & 0.20 & 0.55 & 0.83 & 1.03 \\
\hline CPI inflation & -0.18 & -0.14 & -0.07 & -0.07 \\
\hline Real private consumption & 0.18 & 0.41 & 0.56 & 0.65 \\
\hline Unemployment & 0.53 & 0.83 & 0.86 & 0.85 \\
\hline Private-sector employment & 0.24 & 0.68 & 1.01 & 1.22 \\
\hline Terms of Trade & 0.29 & 0.70 & 0.95 & 1.12 \\
\hline \multicolumn{5}{|l|}{ Public wages } \\
\hline Real GDP & 0.38 & 1.10 & 1.55 & 1.83 \\
\hline CPI inflation & -0.63 & -0.23 & -0.12 & -0.14 \\
\hline Real private consumption & -0.14 & 0.43 & 0.75 & 0.93 \\
\hline Unemployment & -0.53 & -1.47 & -1.99 & -2.25 \\
\hline Terms of Trade & 0.86 & 1.60 & 1.98 & 2.27 \\
\hline \multicolumn{5}{|l|}{ Public investment } \\
\hline Real GDP & -0.63 & -0.45 & -0.38 & -0.36 \\
\hline CPI inflation & -0.53 & -0.04 & 0.00 & -0.04 \\
\hline Real private consumption & 0.19 & 0.44 & 0.55 & 0.59 \\
\hline Unemployment & 0.80 & 0.51 & 0.38 & 0.32 \\
\hline Terms of Trade & 0.72 & 0.88 & 0.88 & 0.86 \\
\hline \multicolumn{5}{|l|}{ Labor income taxes } \\
\hline Real GDP & -0.16 & -0.18 & -0.23 & -0.31 \\
\hline CPI inflation & -0.01 & 0.06 & 0.01 & -0.04 \\
\hline Real private consumption & -0.61 & -0.58 & -0.58 & -0.62 \\
\hline Unemployment & 0.22 & 0.27 & 0.38 & 0.50 \\
\hline Terms of Trade & -0.01 & -0.15 & -0.22 & -0.23 \\
\hline \multicolumn{5}{|l|}{ VAT } \\
\hline Real GDP & -0.11 & -0.05 & -0.02 & -0.04 \\
\hline CPI inflation & 1.45 & -0.02 & -0.01 & -0.05 \\
\hline Real private consumption & -0.42 & -0.38 & -0.37 & -0.40 \\
\hline Unemployment & 0.15 & 0.08 & 0.07 & 0.12 \\
\hline Terms of Trade & 0.08 & 0.07 & 0.08 & 0.11 \\
\hline
\end{tabular}

Source: The table shows annual averages of percentage deviations from initial steady state (percentage point deviations for unemployment and inflation rates). CPI inflation is after VAT and in annualized terms. 


\subsection{Long-run effects}

Table 5 reports the steady-state effects of the different fiscal measures discussed before. We will henceforth refer to such steady-state changes as the 'long-run' effects of our fiscal measures. The table presents percentage deviation from the initial steady state for selected variables (percentage point deviations for any $X$-to-GDP ratio, inflation, interest rates and tax rates). The long-run effects are the result both of the permanent change in the corresponding fiscal instrument and of the long-run reduction in the labor income tax rate implied by our fiscal rule (see section 3.1). The latter effect can be thought of as the long-run benefit of fiscal consolidation. The long-run saving in interest payments on outstanding public debt could alternatively be used to decrease other distortionary taxes (such as consumption taxes or social security contributions), or to increase some expenditure component. As is stressed in Coenen et al. (2010b), the long-run benefits of fiscal consolidation depend to some extent on what is done with the additional proceeds resulting from lower interest payments on outstanding debt. ${ }^{14}$

The following findings stand out. Of all the measures considered, the reduction in public investment $\left(I^{g}\right)$ is the only one that implies a long-run contraction in real GDP, whereas it implies the lowest reduction in the unemployment rate. Therefore, the long-run negative effect on private-sector productivity seems to be dominating the beneficial effects of reduced taxation on labor income. Furthermore, it is the measure with the smallest long-run impact on the public debt-to-GDP ratio. On the contrary, the reduction in public purchases $\left(C^{g}\right)$ has positive effects on real GDP, implying that the reduction in distortionary taxation dominates in the long-run. On the other extreme, cuts in public sector wages seem to produce the best outcomes in terms of real GDP increases and reductions in the unemployment rate. In this case, the long-run fall in distortionary labor income taxation only reinforces the positive spillover effects of this measure on the international competitiveness of the private sector. It also implies the largest fall in the debt-to-GDP ratio. The reduction on public employment follows next in terms of real GDP increases and debt reduction, although to a notable distance. Regarding consolidation on the revenue side, we see the long-run effects of increase in labor income taxation and VAT fall somewhere in between, although the VAT rise generally produces better outcomes thanks to a larger reduction in the labor income tax rate.

Summing up, a reduction in public wages - with the caveats described in the previous section to be borne in mind - seems to be the preferred choice for the purpose of fiscal consolidation, in terms of its long-run beneficial effects on employment and production. Also, a reduction in public employment, a decrease in government purchases as well as increases in VAT and labor income tax rates seem to produce relatively benign long-term outcomes. A cut in public investment, however, is likely to be a less desirable choice given its long-run negative effects on private-sector productivity. This holds unless what is declared to be investment in national accounting is not productivity-enhancing and should rather belong to public purchases in terms of our model.

\footnotetext{
${ }^{14}$ The ESCB's WGEM conducted various fiscal policy experiments in different DSGE models (including FiMod). A common finding in all these models was that using labor income taxes as the (final) fiscal instrument to take care of the lower interest payments resulting from reduced debt-to-GDP ratios is most beneficial. Hence, the gains reported here are, in this respect, likely to be the highest gains that can be achieved in this class of model.
} 
Table 5: Long-run results of different fiscal measures

\begin{tabular}{lrrrrrr}
\hline Measure I & $\Delta \bar{C}^{g}$ & \multicolumn{3}{c}{$\Delta \bar{\tau}^{c}$} & $\Delta \bar{w}^{g}$ \\
Effect on & & \multicolumn{1}{c}{$\Delta \bar{\tau}^{w}$} & & $\Delta \bar{N}^{g}$ & & $\Delta \bar{I}^{g}$ \\
\hline Real GDP & 0.22 & 0.13 & 0.69 & 1.07 & 3.80 & -0.71 \\
Real private-sector output & 0.30 & 0.15 & 0.79 & 2.83 & 4.35 & -0.79 \\
Real private consumption & 1.58 & 0.13 & 0.66 & 2.33 & 3.60 & 0.69 \\
Real private investment & -0.21 & 0.10 & 0.51 & 1.79 & 2.78 & -0.89 \\
Real exports & 1.56 & 0.17 & 0.88 & 3.11 & 4.83 & 0.36 \\
Real imports & 0.19 & 0.02 & 0.11 & 0.37 & 0.57 & 0.05 \\
Unemployment & -0.40 & -0.13 & -0.68 & -0.17 & -3.76 & -0.07 \\
Av private real wage & -0.86 & -0.11 & -0.55 & -1.66 & -3.10 & -1.06 \\
Real unit labor costs & -0.55 & -0.07 & -0.38 & -1.06 & -2.19 & -0.17 \\
Terms of trade & 1.37 & 0.15 & 0.77 & 2.73 & 4.23 & 0.32 \\
Debt/GDP (annualised) & -7.96 & -7.02 & -8.67 & -9.90 & -18.05 & -6.33 \\
Deficit/GDP & 0.22 & 0.19 & 0.24 & 0.27 & 0.50 & 0.18 \\
Primary Deficit/GDP & 0.29 & 0.26 & 0.32 & 0.37 & 0.67 & 0.23 \\
Long-run $d \bar{\tau}^{w}$ & -3.19 & -0.62 & -3.47 & -3.96 & -7.22 & -2.53 \\
\hline
\end{tabular}

Source: Shows percentage deviations from initial steady state (percentage point deviations for tax rates, interest rates, (un)employment rates, inflation and $X$-to-GDP ratios).

\section{Additional analysis: simulating fiscal devaluation}

In this section, we conduct simulations aimed at illustrating some of the additional model applications. Closely related to the discussion in the previous section, we simulate the situation in which the VAT rate is permanently increased in order to decrease social security contributions. Hence, we do not use labor income taxes to sap the proceeds resulting from savings on interest payments on outstanding debt, but adjust instead social security contributions immediately. Such a measure is discussed in several countries (and has partly been carried out in Germany in 2007) and is interpreted as a way of performing "fiscal devaluation" inside a monetary union. We will address the spillovers of this measure o the rest of EMU.

It is well-known that the structure of taxation differs significantly between European countries. Some rely more on direct taxation, while others use indirect taxation such as the consumption tax in our model to finance government expenditures. There is an ongoing debate on whether output and employment prospects of a country can be improved by shifting the tax structure from direct (i.e. labor/income) to indirect (i.e. consumption) taxation; see European Commission (2008). Germany has been criticized for improving its international competitiveness at the cost of other member states by increasing the VAT rate by three percentage points while simultaneously lowering the social security contributions in 2007 . It has to be noted, however, that revenues resulting from only one percentage point of the VAT increase were used to lower social security contributions, the rest was used for consolidation purposes.

In FiMod, we simulate the effects that occur when a similar policy measure is conducted in Spain. We assume that the VAT rate is permanently increased such that the primary deficit-to-GDP ratio is decreased by one percentage point ex ante as described in Sec- 
tion 3.1. Instead of using the savings in interest payments on outstanding debt to decrease labor income taxes, we now reduce social security contributions in the home country (Spain). Social security contribution immediately adapt to the deviations of the targeted debt-to-GDP ratio. This implies that, as the debt-to-GDP ratio decreases, social security contribution do so as well. In terms of our model, we assume that, in the home country (Spain), the fiscal instrument used are social security contributions with $\rho_{\tau^{s c}}=0$ (no smoothing) and $\phi_{\tau^{s c}}=1$ (high stance on deviations of debt from target); see equation (39). The foreign country (rest of EMU), uses lump sum taxes as fiscal instrument. Figure 7 shows the transitional dynamics of selected variables in Spain, while Figure 8 shows the same transitional dynamics in the rest of EMU in order to analyze spillovers. Long-run effects are summarized in Table 6.

Before describing the effects, we have to note that the exercise should be considered as an illustrative example for what FiMod predicts to happen when Spain conducts this measure. As has been shown by Lipinska and von Thadden (2009), the effects - especially the spillovers to the other country - depend considerably on the size of the home country, on the speed of adjustment in other fiscal variables, on the foreign asset positions, on the monetary policy associated with such a measure and on whether the shift is anticipated or not. We abstract from a detailed robustness analysis as the issue is not the main focus of our paper. Interested readers are, however, referred to Lipinska and von Thadden (2009).

Figure 7: Effects of fiscal devaluation (Spain)
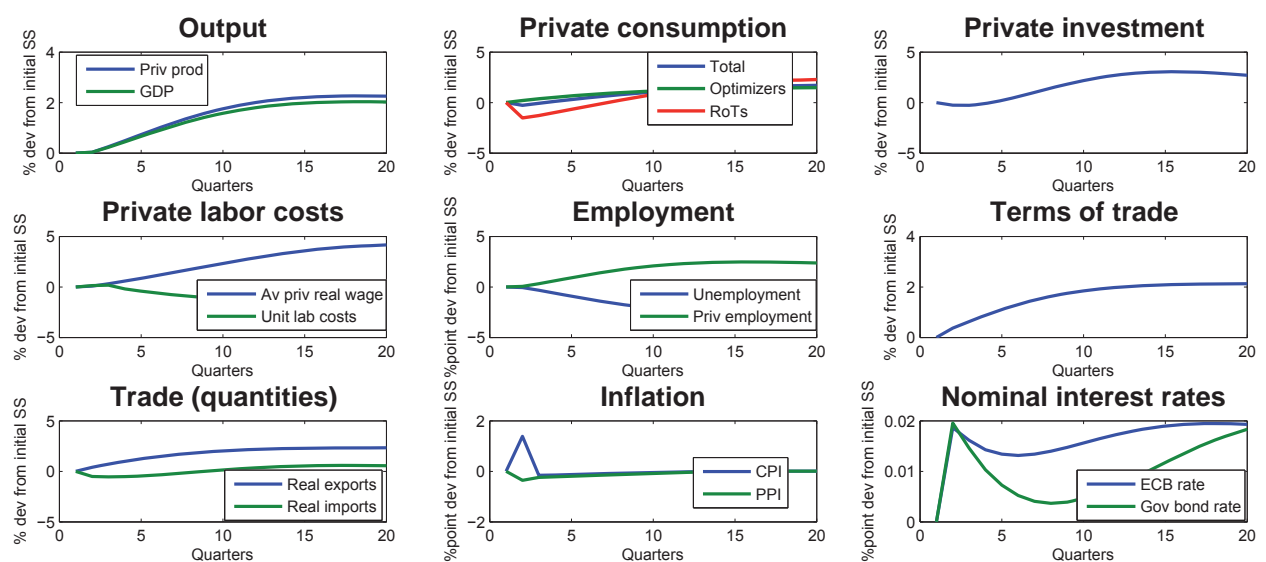

Primary deficit (to GDP ratio)
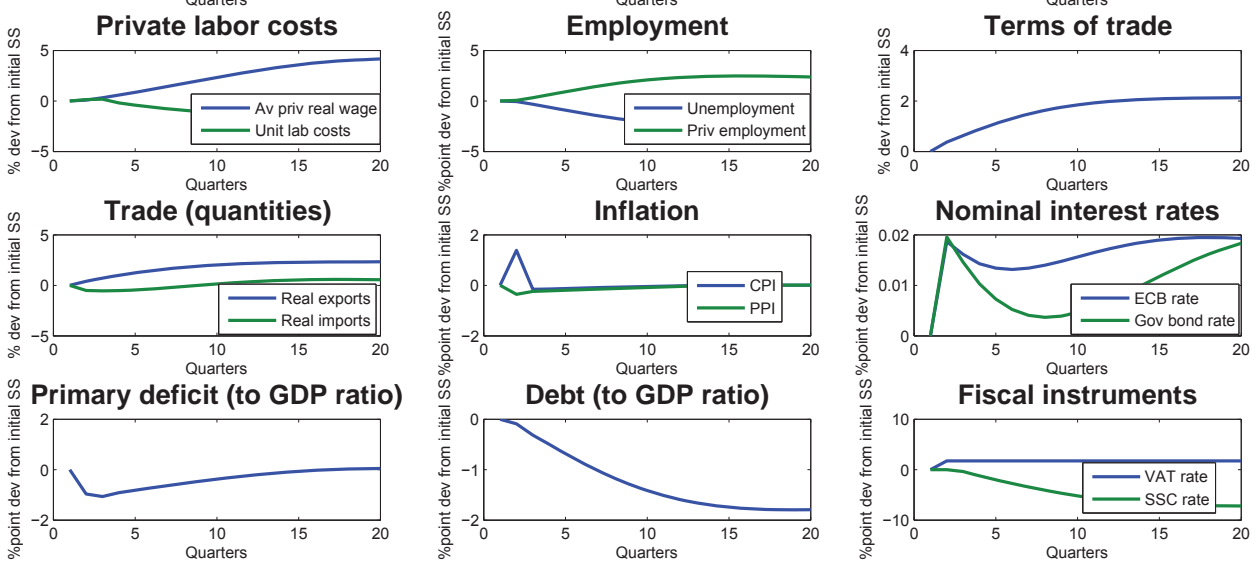

Notes: Transition dynamics of selected home country variables following a permanent increase in the VAT rate to reduce social security contributions. The figure shows percentage deviations from initial steady state (percentage point deviations for interest rates, inflation and X-to-GDP ratios as well as the tax rate itself). Note that CPI inflation is after-VAT.

We see in Figure 7 that the increase in the VAT rate in Spain induces RoT households to consume less, which is not surprising as consumption goods become more expensive. Anticipating the positive wealth effect already described, Ricardian households immedi- 
ately increase consumption. Output increases gradually towards its new steady-state value, thanks to the increase in domestic demand for home goods as well as in exports. As the increase in VAT is used to reduce decrease social security contributions, this reduces unit labor costs inducing firms to employ more workers. Lower unemployment increases the workers' fall-back position in the bargaining process making them demand higher wages. Higher wages and less unemployment eventually reverse the initial drop RoT households' consumption. Lower unit labor costs allows firms to reduce prices (PPI inflation falls) which increases the terms of trade and fosters exports because, in relative terms, Spanish goods become cheaper. This also reduces imports on impact but, as consumption and investment demand eventually increase, imports start to increase too. Higher production and more employment increases marginal capital productivity and, thus, private investment. The fiscal position of Spain, especially the debt-to-GDP ratio, improves even though social security rates are decreased. ${ }^{15}$

Figure 8: Effects of fiscal devaluation (rest of EMU)
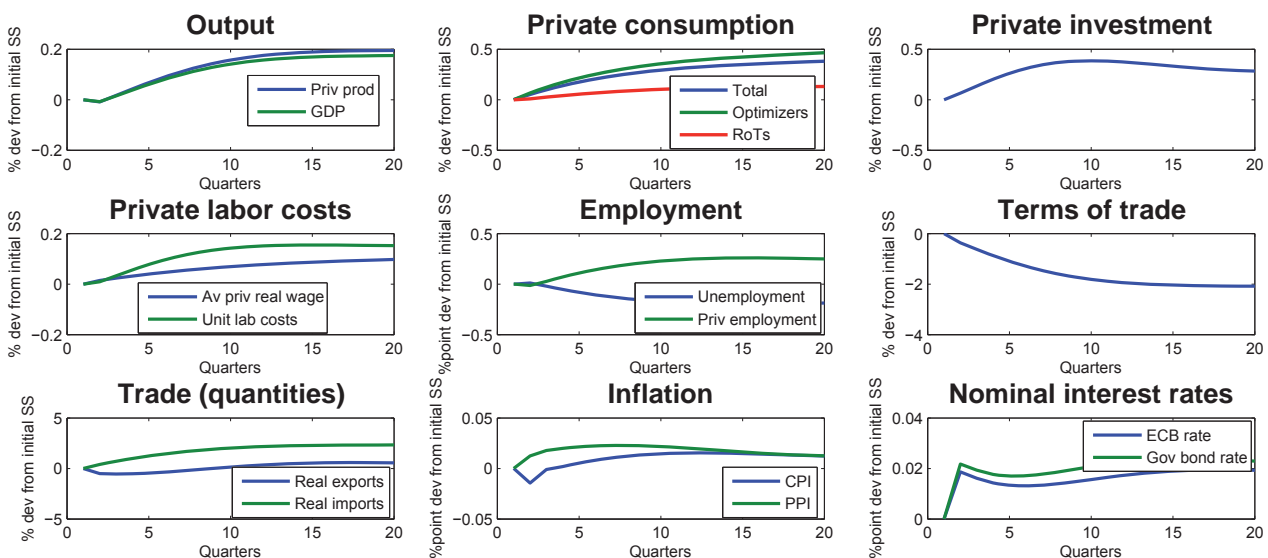

क Primary deficit (to GDP ratio)
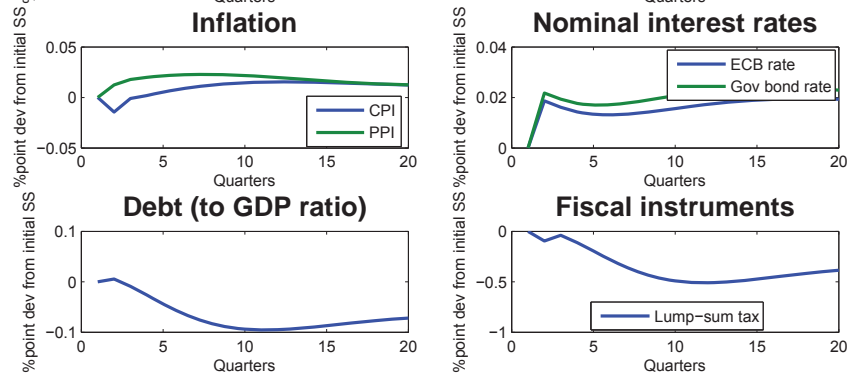

Notes: Transition dynamics of selected home country variables following a permanent increase in the VAT rate to reduce social security contributions. The figure shows percentage deviations from initial steady state (percentage point deviations for interest rates, inflation and X-to-GDP ratios as well as the tax rate itself).

The rest of EMU is influenced by the measure conducted in Spain mainly through two channels, which can be retraced in Figure 8. First, monetary policy increases the policy rate

\footnotetext{
${ }^{15}$ Note that this is partly due to the simulation design. As we did not change the long-run target for the social security contribution rate $\bar{\tau}^{s c}$ nor the targeted debt-to-GDP ratio $\omega^{b}$, the rule itself (and its parameters) influences the final social security rate and, thus, the final debt-to-GDP ratio in the new steady-state. One could change the simulation design such that a differently determined final steady-state social security rate and/or debt-to-GDP ratio is reached. This influences the long-run equilibrium and also the dynamics potentially. As the question of fiscal devaluation is not the main focus of our paper, however, we neglect a more detailed analysis of this issue.
} 
and, second, trade is affected because Spain has improved its international competitiveness (i.e. exports to Spain fall while imports from Spain increase). On impact, output in the rest of EMU stays fairly constant and, then, starts to increase even though Spain has increased its competitiveness. The increase can be explained by the eventual increase in demand for rest-of-EMU products in Spain. As (purchasing) prices for Spanish goods fall in the rest of EMU, those consumers can devote some of these consumption expenditures to home country goods. This holds for RoT and optimizing households, while the latter augment consumption more anticipating the positive spillovers. This also makes them invest more. Higher demand for goods implies an increase in production and, thus, employment which, in turn, increases wages and unit labor costs. The latter increase more as the additional wage costs and higher employment overcompensate the increase in production. Fiscal balances in the rest of EMU increase. Compared to Spain, the effects are relatively small. Note, however, that these positive spillovers and the magnitude of the effects depend on home country size and the degree of home bias in consumer preferences. We will discuss this issue at the end of the section.

Table 6: Long-run effects of fiscal devaluation conducted in Spain

\begin{tabular}{lrr}
\hline & Spain & \\
& & Rest of EMU \\
\hline Real GDP & 2.31 & 0.40 \\
Real private consumption & 2.25 & 0.72 \\
Real private investment & 1.76 & 0.62 \\
Real exports & 2.94 & 0.52 \\
Real imports & 0.52 & 2.94 \\
Unemployment & -2.26 & -0.25 \\
Av private real wage & 4.84 & 0.29 \\
Real unit labor costs & -1.23 & 0.18 \\
Terms of trade & 2.41 & -2.35 \\
Debt/GDP (annualized) & -1.82 & -0.14 \\
Deficit/GDP & 0.05 & 0.00 \\
Primary Deficit/GDP & 0.07 & 0.01 \\
$d \tau^{s c}$ & -7.27 & n.a. \\
$d \bar{\tau}^{c}$ & 1.75 & n.a. \\
Change in lump-sum tax & n.a. & -0.71 \\
\hline
\end{tabular}

Source: The figure shows percentage deviations from initial steady state (percentage point deviations for tax rates, interest rates, (un)employment rates, inflation and $X$-to-GDP ratios).

Our simulation suggests that, in the long-run, the shift in the Spanish tax structure by relying more on indirect taxation and decreasing social security contributions primarily improves Spain's economic situation, while the effects on the rest of EMU are generally very small - but positive, too (see Table 6). So, for a (relatively small) single country, fiscal devaluation as just described fosters economic prospects according to our model. However, we must again stress that the effects are sensitive to country size, the home bias, the precise simulation design and the parametrization of the fiscal rule(s). Furthermore, in our baseline calibration, we find that Spain is relatively less competitive with respect to the rest of EMU (i.e. $\bar{p}_{B}<1$ ). Increasing competitiveness here through "fiscal devaluation" also implies that, 
because of lower prices for Spanish goods, consumption opportunities for rest of EMU in their own country citizens can be improved due to "overall efficiency gains". If we would consider a larger country which is already more competitive than the rest of EMU and has potentially less home bias, the positive spillovers found here could change sign. A more profound analysis of this question, also in our model, is certainly interesting but is beyond the scope of our paper. We should also bear in mind that the simulations shown here do not include strategic interaction of the rest of EMU-countries with policy measures conducted in Spain - an issue that certainly becomes the more important the larger the economy conducting fiscal devaluation is. Again, the reader is referred to Lipińska and von Thadden (2009) for a more detailed discussion.

\section{Conclusions}

In this paper, we develop a dynamic stochastic general equilibrium (DSGE) model of a twocountry monetary union economy with a comprehensive fiscal block. Our model is primarily aimed at simulating the effects of fiscal policy measures by relatively large countries (such as Germany, France, Italy or Spain) in a monetary union such as the Euro Area. We provide a notable degree of disaggregation on the fiscal expenditures side, explicitly distinguishing between (productivity-enhancing) public investment, public purchases, and the public sector wage bill. We also consider a wide range of taxes on the fiscal revenues side. The model incorporates various other realistic features such as frictional labor markets and equilibrium unemployment, staggered price setting and wage bargaining in the private sector, liquidityconstrained households, habit formation, and investment adjustment costs. It is calibrated for Spain and the rest of the Euro Area, but it can easily be re-calibrated for other member states.

Inspired by recent fiscal actions and announcements in Spain, we simulate a number of policy measures aimed at achieving fiscal consolidation. We find that using cuts in public investment is probably the less desirable way of performing fiscal consolidation, in terms of both its short-run and long-run effects on economic activity. The effects of public consumption cuts depend on which specific measure is taken: whereas cuts in public purchases tend to be relatively harmful in the short-run due to its direct effect on aggregate demand, reductions in public sector wages or employment have positive spillover effects on the private sector thanks to lower labor costs and improved international competitiveness. Finally, we find that, in a labor market characterized by matching frictions and wage bargaining, increases in labor income or consumption taxes do not seem to affect production and output as much as they do in conventional models incorporating a Walrasian labor market. We also show that a shift of direct to indirect tax-financing of government expenditures can improve Spain's competitiveness while its effects on the rest of EMU are also positive, but rather small. 


\section{References}

Afonso, A. AND P. Gomes [2008], “Interactions Between Private and Public Sector Wages," European Central Bank, Working Paper, No. 971, Frankfurt am Main.

Albrecht, J., L. NAVARRO AND S. VROMAN [2009], "The Effects of Labor Market Policies in an Economy with an Informal Sector," The Economic Journal, 119, 1105-1129.

Almeida, V., G. CAstro, R. M. FÉlix AND J. F. Maria [2010], "Fiscal Stimulus in a Small Euro Area Economy," Bank of Portugal, Working Paper, No. 16/2010, Lisbon.

Alvarez, L.J., E. Dhyne, M. Hoeberichts, C. KWAPIL, H. Le Bihan, P. LÜNNemanN, F. Martins, R. Sabbatini, H. Stahl, P. Vermeulen, and J. Vilmunen [2006], "Sticky Prices in the Europe Area: A Summary of New Micro-Evidence," Journal of the European Economic Association, 4, 575-584.

AndolfatTO, D. [1996], "Business Cycles and Labor-Market Search," American Economic Review, 86, 112-132.

Argimón, I., F. DE CASTRO AND A.L. Gómez [2007], “Una Simulación de los Efectos de la Reforma del IRPF sobre la Carga Impositiva," Banco de España, Occasional Paper, No. 702, Madrid.

Aschauer, D. A. [1989], “Does Public Capital Crowd Out Private Capital?,” Journal of Monetary Economics, 24, 171-188.

Barro, R. J. [1979], “On the Determination of Public Debt," Journal of Political Economy, 87, 940-971.

Blanchard, O. And J. Galí [2007], "Real Wage Rigidities and the New Keynesian Model," Journal of Money, Credit and Banking, 39, 35-65.

Blanchard, O. AND J. Galí [2010], "Labor Markets and Monetary Policy: A NewKeynesian Model with Unemployment," American Economic Journal: Macroeconomics, 2, 1-30.

Bodart, V., O. Pierrard And H. S. Snessens [2006], "Calvo Wages in a Search Unemployment Model," Institute for the Study of Labor (IZA), Discussion Paper, No. 2521, Bonn.

Boscá, J. E., A. Díaz, R. Doménech, E. Pérez, J. Ferri And L. Puch [2010], “A Rational Expectations Model for Simulation and Policy Evaluation of the Spanish Economy," SERIEs - Journal of the Spanish Economic Association, 1, 135-169.

BoscÁ, J. E., R. DOMÉNECH AND J. FERRi [2009a], “Tax Reforms and Labour-Market Performance: An Evaluation for Spain Using REMS," Banco Bilbao Vizcaya Argentaria (BBVA), Working Paper, No. 0908, Madrid.

BOSCÁ, J. E., R. DOMÉNECH AND J. FERRI [2009b], "Search, Nash Bargaining and Rule of Thumb Consumers," Banco Bilbao Vizcaya Argentaria (BBVA), Working Paper, No. 0910, Madrid.

Brulhart, M. AND F. TRIONFETti [2004], “Public Expenditure, International Specialisation and Agglomeration," European Economic Review, 48, 851-881.

Burda, M. AND M. WEDER [2002], "Complementarity of Labor Market Institutions, Equilibrium Unemployment and the Propagation of Business Cycles," German Economic Review, 3, 1-24.

Calvo, G. [1983], "Staggered Prices in a Utility-Maximizing Framework," Journal of Monetary Economics, 12, 383-398.

Canzoneri, M. B., R. Cumby, B. Diba And J. D. Lóopez-Salido [2008], "Monetary and Fiscal Policy Coordination when Bonds Provide Transactions Services," Center 
for Economic Policy Research (CEPR), Discussion Paper Series, No. 6814, London.

Christiano, L., M. Eichenbaum and C. Evans [2005], "Nominal Rigidities and the Dynamic Effects of a Shock to Monetary Policy," Journal of Political Economy, 113, 1-45.

Christiano, L., M. Eichenbaum And S. Rebelo [2009], "When is the Government Spending Multiplier Large?," National Bureau of Economic Research (NBER), Working Paper, No. 15394, Cambridge, MA.

Christoffel, K., G. Coenen AND A. WARne [2008], “The New Area-Wide Model of the Euro Area - A Micro-Founded Open-Economy Model for Forecasting and Policy Analysis," European Central Bank, Working Paper (ECB), No. 944, Frankfurt am Main.

Christoffel, K., K. Kuester AND T. Linzert [2009], “The Role of Labor Markets for Euro Area Monetary Policy," European Economic Review, 53, 908-936.

Coenen, G., C. Erceg, C. Freedman, D. Furceci, M. Kumhof, R. Lalonde, D. Laxton, J. Lindé, A. Mourougane, A. Muir, S. Mursula, C. De Resende, J. Roberts, W. Röeger, S. SNudden, M. Trabandt AND J. IN'T Veld [2010a], “Effects of Fiscal Stimulus in Structural Models," International Monetary Fund (IMF), Working Paper, No. 10/73, Washington, DC.

Coenen, G., J. Kilponen And M. Trabandt [2010b], “When Does Fiscal Stimulus Work?," European Central Bank (ECB), Research Bulletin, 10, 6-10.

Coenen, G., P. McAdam And R. Straub [2008], “Tax Reform and Labour-Market Performance in the Euro Area: A Simulation-Based Analysis Using the New Area-Wide Model," Journal of Economics Dynamics and Control, 32, 2543-2583.

COGAN, J. F., T. CWIK, J. B. TAYLOR AND V. Wieland [2009], "New Keynesian versus Old Keynesian Government Spending Multipliers," National Bureau of Economic Research (NBER), Working Paper, No. 14782, Cambridge, MA.

Colciago, A., T. Ropele, V.A. Muscatelli AND P. TiRelli [2008], "The Role of Fiscal Policy in a Monetary Union: Are National Automatic Stabilizers Effective?," Review of International Economics, 16, 591-610.

CoOley, T. F. AND E. C. PResCott [1995], “Economic Growth and Business Cycles,” pp. 138 in: T. F. Cooley (ed), Frontiers in Business Cycle Research, Princeton University Press, Princeton, NJ.

Del Negro, M., F. Schorfheide, F. Smets And R. Wouters [2005], "On the Fit and Forecasting Performance of New Keynesian Models," European Central Bank, Working Paper, No. 491, Frankfurt am Main.

De Walque, G., O.Pierrard, H. S. Snessens And R. Wouters [2009], “Sequential Bargaining in a New-Keynesian Model with Frictional Unemployment and Wage Negotiation," European Central Bank, Working Paper, No. 1007, Frankfurt am Main.

EGgertsson, G. B. [2009], “What Fiscal Policy is Effective at Zero Interest Rates?," Federal Reserve Bank of New York, Staff Report No. 402, New York, NY.

ERCeG, C., D. Henderson AND A. Levin [2000], “Optimal Monetary Policy with Staggered Wage and Price Contracts," Journal of Monetary Economics, 46, 281-313.

ERCEG, C. AND J. LiNDÉ [2010], "Is there a Free Lunch in a Liquidity Trap?," Center for Economic Policy Research (CEPR), Discussion Paper Series, No. 7624, London.

European COMmission [2008], "Public Finances in EMU - 2008," European Economy 8, Brussels.

FORNI, L., L. MONTEFORTE AND L. SESSA [2009], “The General Equilibrium Effects of Fiscal Policy: Estimates for the Euro Area," Journal of Public Economics, 93, 559-585. 
Freedman, C., M. Kumhof, D. Laxton, A. Muir And S. Mursula [2009], "Fiscal Stimulus to the Rescue? Short-run Benefits and Potential Long-run Costs of Fiscal Deficits," International Monetary Fund (IMF), Working Paper, No. 09/255, Washington, DC.

Galí, J., J. D. LOPEZ-SALIDO AND J. VAllÉS [2007], "Understanding the Effects of Government Spending on Consumption," Journal of the European Economics Association, 5, 227-270.

Galí, J. AND T. MonaCelli [2008], “Optimal Monetary and Fiscal Policy in a Currency Union," Journal of International Economics, 76, 116-132.

Gomes, P. [2009], "Labour Market Effects of Public Sector Employment and Wages", London School of Economics, Working Paper, January 29, 2009, London, available at: http://econ.lse.ac.uk/faq/mresphd/otherfiles/EDPpapers/Jamboree2009_ Gomes.pdf/.

Gomes, S., P. Jacquinot And M. PisAni [2010], "The EAGLE: A Model for Policy Analysis of Macroeconomic Interdependence in the Euro Area," European Central Bank, Working Paper, No. 1195, Frankfurt am Main.

Hall, R. E. [2009], "By How Much Does GDP Rise if the Government Buys More Output?," National Bureau of Economic Research (NBER), Working Paper, No. 15496, Cambridge, MA.

Hebous, S. [2010], "The Effects of Discretionary Fiscal Policy on Macroeconomic Aggregates: A Reappraisal," Journal of Economic Surveys, forthcoming.

Holtz-EaKin, D. [1994], "Public-Sector Capital and the Productivity Puzzle," Review of Economics and Statistics, 76, 12-21.

KAMPs, C. [2004], "The Dynamic Macroeconomic Effects of Public Capital," Springer, Berlin, Germany.

Kilponen, J. AND A. RipatTi [2005], "Labour and Product Market Competition in a Small Open Economy - Simulation Results Using a DGE Model of the Finnish Economy," Bank of Finland, Research Discussion Papers, No. 5/2005, Helsinki.

Kirsanova, T. AND S. Wren-Lewis [2007], "Optimal Fiscal Feedback on Debt in an Economy with Nominal Rigidities," mimeo, University of Exeter, Exeter, Devon, UK.

LEEPER, E. M., T. B. WALKeR AND S. C. S. YANG [2010], "Government Investment and Fiscal Stimulus," Journal of Monetary Economics, 57, 1000-1012.

LeITH, C. AND S. Wren-LeWIS [2007], "Countercyclical Fiscal Policy: Which Instrument is Best?," Working Paper, University of Glasgow, Department Working Papers, No. 2005/03, extended version of The Cost of Fiscal Inflexibility.

LiPIŃSKA, A. AND L. VON THADDEn [2009], "Monetary and Fiscal Policy Aspects of Indirect Tax Changes in a Monetary Union," European Central Bank, Working Paper (ECB), No. 1097, Frankfurt am Main.

Lucas, R. And N. Stokey [1983], "Optimal Fiscal and Monetary Policy in an Economy Without Capital," Journal of Monetary Economics, 12, 55-93.

MERZ, M. [1995], "Search in the Labor Market and the Real Business Cycle," Journal of Monetary Economics, 36, 269-300.

MOYEN, S. AND N. STÄHLER [2009], "Unemployment Insurance and the Business Cycle: Prolong Benefit Entitlement in Bad Times?," Bundesbank Discussion Paper Series 1: Economic Studies, No. 30/2009, Frankfurt am Main.

NAdiRI, M. I. AND T. P. MAmuneas [1994], "The Effects of Public Infrastructure and R\& D Capital on the Cost Structure and Performance of US Manufacturing Industries," Review of Economics and Statistics, 76, 22-37. 
Oswald, A. J. [1993], "Efficient Contracts on the Labour Demand Curve: Theory and Evidence," Labour Economics, 1, 85-113.

Petrongolo, B. And C. Pissarides [2001], "Looking into the Black Box: A Survey of the Matching Function," Journal of Economic Literature, 39, 390-431.

PISSARIDES, C. [2000], "Equilibrium Unemployment Theory," MIT Press, second edition, Cambridge, MA.

PISSARIDES, C. [2009], “The Unemployment Volatility Puzzle: Is Wage Stickiness the Answer?," Econometrica, 77, 1339-1369.

QUADrini, V. AND A. TRIGARI [2007], "Public Employment and the Business Cycle," Scandinavian Journal of Economics, 109, 723-742.

Ratto, M., W. RÖEgER AND J. IN’T VelD [2009], “QUEST III: A Estimated Open-Economy DSGE Model of the Euro Area with Fiscal and Monetary Policy," Economic Modelling, 26, 222-233.

SChmitT-Grohé, S. AND M. URIBe [2003], “Closing Small Open Economy Models,” Journal of International Economics, 61, 163-185.

SchmitT-Grohé, S. AND M. URibe [2006], “Optimal Fiscal and Monetary Policy in a Medium-Scale Macroeconomic Model," pp. 383-425 in: M. Gertler and K. Rogoff (eds), NBER Macroeconomics Annual 2005, MIT Press, Cambridge, MA.

SChMitT-Grohé, S. AND M. URIBE [2007], "Optimal Simple and Implementable Monetary and Fiscal Rules," Journal of Monetary Economics, 54, 1702-1725.

SILVA, J. I. AND M. E. TOLEDO [2009], "Labor Turnover Costs and the Cyclical Behavior of Vacancies and Unemployment," Macroeconomic Dynamics, 13, 76-96.

SMETS, F. AND R. WOUTERS [2003], "An Estimated Stochastic General Equilibrium Model of the Euro Area," Journal of the European Economic Association, 1, 1123-1175.

SMETS, F. AND R. WOUTERS [2007], "Shocks and Frictions in US Business Cycles: A Bayesian DSGE Approach," American Economic Review, 97, 586-606.

Straub, R. AND I. TSCHAKAROv [2007], "Assessing the Impact of a Change in the Composition of Public Spending: A DSGE Approach," ECB Working Paper Series, No. 795, Frankfurt am Main.

TAYLOR, J. B. [1993], "Discretion Versus Policy Rules in Practice," Carnegie-Rochester Conference Series on Public Policy, 39, 195-214.

TrionfetTi, F. [2000], “Discriminatory Public Procurement and International Trade," Blackwell Publishers.

Woodford, M. [2001], "The Taylor Rule and Optimal Monetary Policy," American Economic Review, 91, 232-237. 


\section{BANCO DE ESPAÑA PUBLICATIONS}

\section{WORKING PAPERS ${ }^{1}$}

1001 JAVIER ANDRÉS, ÓSCAR ARCE AND CARLOS THOMAS: Banking competition, collateral constraints and optimal monetary policy.

1002 CRISTINA BARCELÓ AND ERNESTO VILLANUEVA: The response of household wealth to the risk of losing the job: evidence from differences in firing costs.

1003 ALEXANDER KARAIVANOV, SONIA RUANO, JESÚS SAURINA AND ROBERT TOWNSEND: No bank, one bank, several banks: does it matter for investment?

1004 GABRIEL PEREZ-QUIROS AND HUGO RODRÍGUEZ MENDIZÁBAL: Asymmetric standing facilities: an unexploited monetary policy tool.

1005 GABRIEL JIMÉNEZ, JOSE A. LOPEZ AND JESÚS SAURINA: How does competition impact bank risk-taking?

1006 GIUSEPPE BERTOLA, AURELIJUS DABUSINSKAS, MARCO HOEBERICHTS, MARIO IZQUIERDO, CLAUDIA KWAPIL, JEREMI MONTORNÈS AND DANIEL RADOWSKI: Price, wage and employment response to shocks: evidence from the WDN Survey.

1007 JAVIER MENCÍA: Testing non-linear dependence in the Hedge Fund industry.

1008 ALFREDO MARTíN-OLIVER: From proximity to distant banking: Spanish banks in the EMU.

1009 GALO NUÑO: Optimal research and development expenditure: a general equilibrium approach.

1010 LUIS J. ÁLVAREZ AND PABLO BURRIEL: Is a Calvo price setting model consistent with micro price data?

1011 JENS HAGENDORFF, IGNACIO HERNANDO, MARÍA J. NIETO AND LARRY D. WALL: What do premiums paid for bank M\&As reflect? The case of the European Union.

1012 DAVID DE ANTONIO LIEDO: General equilibrium restrictions for dynamic factor models.

1013 JAMES COSTAIN, JUAN F. JIMENO AND CARLOS THOMAS: Employment fluctuations in a dual labor market.

1014 LUIS M. VICEIRA AND RICARDO GIMENO: The euro as a reserve currency for global investors.

1015 PALOMA LÓPEZ-GARCÍA AND JOSÉ MANUEL MONTERO: Understanding the Spanish business innovation gap: The role of spillovers and firms' absorptive capacity.

1016 AITOR LACUESTA AND SERGIO PUENTE: El efecto del ciclo económico en las entradas y salidas de inmigrantes en España.

1017 REBEKKA CHRISTOPOULOU, JUAN F. JIMENO AND ANA LAMO: Changes in the wage structure in EU countries.

1018 THOMAS BREUER, MARTIN JANDAČKA, JAVIER MENCÍA AND MARTIN SUMMER: A systematic approach to multi-period stress testing of portfolio credit risk.

1019 LUIS J. ÁLVAREZ AND PABLO BURRIEL: Micro-based estimates of heterogeneous pricing rules: The United States vs. the euro area.

1020 ALFREDO MARTÍN-OLIVER AND VICENTE SALAS-FUMÁS: I.T. investment and intangibles: Evidence from banks.

1021 LUISA LAMBERTINI, CATERINA MENDICINO AND MARIA TERESA PUNZI: Expectations-driven cycles in the housing market.

1022 JULIÁN MESSINA, PHILIP DU CAJU, CLÁUDIA FILIPA DUARTE, NIELS LYNGGÅRD HANSEN AND MARIO IZQUIERDO: The incidence of nominal and real wage rigidity: an individual-based sectoral approach.

1023 ALESSIO MORO: Development, growth and volatility.

1024 LUIS J. ÁLVAREZ AND ALBERTO CABRERO: Does housing really lead the business cycle?

1025 JUAN S. MORA-SANGUINETTI: Is judicial inefficiency increasing the house property market weight in Spain? Evidence at the local level.

1026 MAXIMO CAMACHO, GABRIEL PEREZ-QUIROS AND PILAR PONCELA: Green shoots in the Euro area. A real time measure.

1027 AITOR ERCE AND JAVIER DÍAZ-CASSOU: Creditor discrimination during sovereign debt restructurings.

1028 RAFAEL REPULLO, JESÚS SAURINA AND CARLOS TRUCHARTE: Mitigating the pro-cyclicality of Basel II.

1029 ISABEL ARGIMÓN AND JENIFER RUIZ: The effects of national discretions on banks.

1030 GABRIEL JIMÉNEZ, STEVEN ONGENA, JOSÉ-LUIS PEYDRÓ AND JESÚS SAURINA: Credit supply: identifying balance-sheet channels with loan applications and granted loans.

1031 ENRIQUE MORAL-BENITO: Determinants of economic growth: A Bayesian panel data approach.

1. Previously published Working Papers are listed in the Banco de España publications catalogue. 
1032 GABE J. DE BONDT, TUOMAS A. PELTONEN AND DANIEL SANTABÁRBARA: Booms and busts in China's stock market: Estimates based on fundamentals.

1033 CARMEN MARTÍNEZ-CARRASCAL AND JULIAN VON LANDESBERGER: Explaining the demand for money by nonfinancial corporations in the euro area: A macro and a micro view.

1034 CARMEN MARTíNEZ-CARRASCAL: Cash holdings, firm size and access to external finance. Evidence for the euro area.

1035 CÉSAR ALONSO-BORREGO: Firm behavior, market deregulation and productivity in Spain.

1036 OLYMPIA BOVER: Housing purchases and the dynamics of housing wealth.

1037 DAVID DE ANTONIO LIEDO AND ELENA FERNÁNDEZ MUÑOZ: Nowcasting Spanish GDP growth in real time: "One and a half months earlier".

1038 FRANCESCA VIANI: International financial flows, real exchange rates and cross-border insurance.

1039 FERNANDO BRONER, TATIANA DIDIER, AITOR ERCE AND SERGIO L. SCHMUKLER: Gross capital flows: dynamics and crises.

1101 GIACOMO MASIER AND ERNESTO VILLANUEVA: Consumption and initial mortgage conditions: evidence from survey data.

1102 PABLO HERNÁNDEZ DE COS AND ENRIQUE MORAL-BENITO: Endogenous fiscal consolidations.

1103 CÉSAR CALDERÓN, ENRIQUE MORAL-BENITO AND LUIS SERVÉN: Is infrastructure capital productive? A dynamic heterogeneous approach.

1104 MICHAEL DANQUAH, ENRIQUE MORAL-BENITO AND BAZOUMANA OUATTARA: TFP growth and its determinants: nonparametrics and model averaging.

1105 JUAN CARLOS BERGANZA AND CARMEN BROTO: Flexible inflation targets, forex interventions and exchange rate volatility in emerging countries.

1106 FRANCISCO DE CASTRO, JAVIER J. PÉREZ AND MARTA RODRÍGUEZ VIVES: Fiscal data revisions in Europe.

1107 ANGEL GAVILÁN, PABLO HERNÁNDEZ DE COS, JUAN F. JIMENO AND JUAN A. ROJAS: Fiscal policy, structural reforms and external imbalances: a quantitative evaluation for Spain.

1108 EVA ORTEGA, MARGARITA RUBIO AND CARLOS THOMAS: House purchase versus rental in Spain.

1109 ENRIQUE MORAL-BENITO: Dynamic panels with predetermined regressors: likelihood-based estimation and Bayesian averaging with an application to cross-country growth.

1110 NIKOLAI STÄHLER AND CARLOS THOMAS: FiMod - a DSGE model for fiscal policy simulations.

\begin{tabular}{|r|c|}
\hline & Unidad de Publicaciones \\
\hline BANCODE ESPAÑ & Alcalá 522, 28027 Madrid \\
Eurosistema & Telephone +34 91 3386363. Fax +34913386488 \\
E-mail: publicaciones@bde.es \\
www.bde.es
\end{tabular}

